\title{
DNAzymes, Novel Therapeutic Agents in Cancer Therapy: A Review of Concepts to Applications
}

\author{
I. B. K. Thomas $\mathbb{D}^{1}$ K. A. P. Gaminda $\mathbb{D}^{2}{ }^{2}$ C. D. Jayasinghe $\mathbb{D}^{3},{ }^{3}$ D. T. Abeysinghe $\mathbb{D}^{2}{ }^{2}$ \\ and R. Senthilnithy $\mathbb{1}^{2}$ \\ ${ }^{1}$ Department of Biology, Faculty of Applied Sciences, South Eastern University of Sri Lanka, Sri Lanka \\ ${ }^{2}$ Department of Chemistry, Faculty of Natural Sciences, The Open University of Sri Lanka, Nugegoda, Sri Lanka \\ ${ }^{3}$ Department of Zoology, Faculty of Natural Sciences, The Open University of Sri Lanka, Nugegoda, Sri Lanka
}

Correspondence should be addressed to C. D. Jayasinghe; cdjay@ou.ac.lk

Received 29 June 2021; Accepted 6 October 2021; Published 1 November 2021

Academic Editor: Ashis Basu

Copyright (c) 2021 I. B. K. Thomas et al. This is an open access article distributed under the Creative Commons Attribution License, which permits unrestricted use, distribution, and reproduction in any medium, provided the original work is properly cited.

\begin{abstract}
The past few decades have witnessed a rapid evolution in cancer drug research which is aimed at developing active biological interventions to regulate cancer-specific molecular targets. Nucleic acid-based therapeutics, including ribozymes, antisense oligonucleotides, small interference RNA (siRNA), aptamer, and DNAzymes, have emerged as promising candidates regulating cancer-specific genes at either the transcriptional or posttranscriptional level. Gene-specific catalytic DNA molecules, or DNAzymes, have shown promise as a therapeutic intervention against cancer in various in vitro and in vivo models, expediting towards clinical applications. DNAzymes are single-stranded catalytic DNA that has not been observed in nature, and they are synthesized through in vitro selection processes from a large pool of random DNA libraries. The intrinsic properties of DNAzymes like small molecular weight, higher stability, excellent programmability, diversity, and low cost have brought them to the forefront of the nucleic acid-based therapeutic arsenal available for cancers. In recent years, considerable efforts have been undertaken to assess a variety of DNAzymes against different cancers. However, their therapeutic application is constrained by the low delivery efficiency, cellular uptake, and target detection within the tumour microenvironment. Thus, there is a pursuit to identify efficient delivery methods in vivo before the full potential of DNAzymes in cancer therapy is realized. In this light, a review of the recent advances in the use of DNAzymes against cancers in preclinical and clinical settings is valuable to understand its potential as effective cancer therapy. We have thus sought to firstly provide a brief overview of construction and recent improvements in the design of DNAzymes. Secondly, this review stipulates the efficacy, safety, and tolerability of DNAzymes developed against major hallmarks of cancers tested in preclinical and clinical settings. Lastly, the recent advances in DNAzyme delivery systems along with the challenges and prospects for the clinical application of DNAzymes as cancer therapy are also discussed.
\end{abstract}

\section{Introduction}

Completion of the Human Genome Project has expanded our understanding of the genetic root of many incurable diseases such as cancer, Alzheimer's, Parkinson's, asthma, and rheumatoid arthritis [1]. A new stride in genomic medicine has concocted novel therapeutic options that can modulate the disease outcomes by regulating the disease-specific genes [2]. Recently, nucleic acids, including deoxyribonucleic acid
(DNA) and ribonucleic acid (RNA), have emerged as stand-alone therapeutics that go beyond mere storage and transmission of genetic information [3]. Fundamentally, nucleic acid therapy inhibits either DNA or RNA expression and subsequently halts the production of an abnormal protein associated with a disease while other proteins are unaffected [3]. Further, both DNA and RNA exert catalytic properties that can perform specific chemical reactions, with efficacy comparable to that of protein enzymes [4]. 
Currently, DNA-based therapeutics is at the forefront of genomic medicine due to their specificity in recognizing molecular targets and pathways [3]. DNA-based therapeutics includes plasmids, oligonucleotides for antisense and antigene applications, DNA aptamers, and DNAzymes or deoxyribozymes [5]. Among DNAzymes, they impart tremendous potential in gene suppression [5]. Unlike ribozymes, DNAzymes have not been observed in nature, and all existing molecules result through in vitro selection processes from a random DNA library containing about $10^{15}$ DNA sequences [6]. DNAzymes catalyze an array of chemical reactions, including RNA cleavage, oxidative or hydrolytic DNA cleavage, DNA/RNA ligation, and DNA phosphorylation [6]. The extensively studied RNA-cleaving DNAzymes catalyze the cleavage of a single RNA linkage embedded within a DNA strand [6].

Following the isolation of DNAzymes in 1994, their usage has become ubiquitous in biomedical applications [7]. Their applications in cancer diagnostics and therapeutics are enormous. Cancer possesses a multifactorial etiology where hereditary and acquired defects singly or synergistically cause cellular transformations [8]. Hence, recent years witness a paradigm shift of anticancer drug development from conventional broad-spectrum cytotoxic compounds to molecular interventions that selectively act on specific targets. In the light, DNAzymes present an effective alternative to traditional chemotherapy owing to their specific catalytic activity [9]. Wu et al. [10] were the first to report the potential of DNAzymes as an anticancer agent in vitro. Since then, several DNAzymes have been synthesized, targeting various genes leading to cancer onset and progression [9]. Mainly, RNA-cleaving DNAzymes have been broadly investigated due to their potential to downregulate the target protein by cleaving corresponding mRNA [11]. Although DNAzymes possess high stability and selectivity than ribozymes, the therapeutic applications are limited by the inept delivery to intracellular targets [4]. Hence, critical analysis of their applications in cancer research would provide insight into their effectiveness and prospects as cancer therapy.

This review intends to provide critical analysis of available literature on applications of DNAzymes as an emerging anticancer therapy. Initially, this review will give a brief overview of the structure and synthesis of DNAzymes. Secondly, this review discusses the efficacy, safety, and tolerability of DNAzymes developed against different cancer types. The different DNAzymes developed against the specific molecular target in major hallmarks of cancer such as metastasis, angiogenesis, and apoptosis are discussed separately in this review. Further, the applicability of DNAzymes against cancer-specific alleles and oncogenic viruses has been addressed in this review.

Moreover, we summarize DNAzymes that have currently being evaluated in clinical trials and have obtained regulatory approval. Although DNAzymes have revolutionized the anticancer therapeutic arsenal, they are limited by inefficient delivery to the cancer cells. Consequently, attempts taken so far to enhance cellular delivery of DNAzyme therapeutics accompanied by the apparent challenges involved will be addressed briefly. It is anticipated that this comprehensive review would enlighten the reader about the efficacy of DNAzymes as novel nucleic acid-based therapy against cancer.

\section{DNAzymes: Brief Overview}

In 1994, Breaker and Joyce identified the catalytic property of DNA and isolated the first DNAzymes via an in vitro selection system [7]. The in vitro selection system was based on the hydrolytic cleavage of a phosphodiester and nested PCR [12]. A pool of $10^{15}$ ssDNA molecules containing a $5^{\prime}$ biotin moiety, followed by a 50-randomdeoxyribonucleotide domain flanked by a fixed sequence, was established. Then, these molecules were exposed to a streptavidin affinity matrix and washed with buffer to remove the unbound. Next, the same buffer containing a certain cation passed through the matrix to cause cationdependent cleavage of phosphodiester, and catalytic DNAs were released from the mixture. These DNAs were collected, reintroduced to the $5^{\prime}$ biotin and target phosphodiester, amplified by nested PCR, and finally subjected to several selection rounds [12].

DNAzymes are characterized by two domains: catalytic and substrate binding domains. However, their sequences can be varying. There are two main types: "10-23" and " 8 17 " DNAzymes (Figure 1) isolated from the in vitro selection system [12]. The "10-23" DNAzyme has been obtained from the $23^{\text {rd }}$ clone after 10 rounds of amplification, while " $8-17$ " DNAzyme has been obtained from the $17^{\text {th }}$ clone after 8 rounds of amplification [12]. The catalytic core of " $8-17$ " DNAzyme consists of $13 \mathrm{nt}$, having a short internal stem loop connected to an unpaired region of $4 \mathrm{nt}$. The loop contains a fixed sequence of $5^{\prime}-\mathrm{AGC}-3^{\prime}$. The sequence of an unpaired region represents $5^{\prime}$-WCGR- $3^{\prime}$ or $5^{\prime}$-WCGAA$3^{\prime}(\mathrm{W}=\mathrm{A} / \mathrm{T}, \mathrm{R}=\mathrm{A} / \mathrm{G})$ [12]. In the "10-23" DNAzyme, the catalytic core is composed of $15 \mathrm{nt}$, while the $8^{\text {th }}$ of which was usually $\mathrm{T}, \mathrm{C}$, or $\mathrm{A}$ and $\mathrm{T}$ often provides the highest activity [12].

The catalytic core binds to and cleaves its target RNA through a deesterification reaction. Two arms flank the core, each composed of a substrate recognition domain of 7-9 nt facilitating the binding to RNA substrate via the WatsonCrick hybridization. Ultimately, the substrate strand splits at the cleavage site giving rise to $5^{\prime}$ and $3^{\prime}$ products which comprise a $2^{\prime}, 3^{\prime}$-cyclic phosphate and $5^{\prime}$-hydroxyl terminus, respectively (Figure 2) [13]. The "10-23" DNAzyme can cleave almost any phosphodiester bond between an unpaired purine and paired pyrimidine [14]. Most DNAzymes are assisted by specific metal ions such as $\mathrm{Mg}^{2+}$, $\mathrm{Pb}^{2+}, \mathrm{Mn}^{2+}, \mathrm{Cu}^{+2}$, and $\mathrm{Na}^{+}$that function as cofactors contributing to achieving a satisfactory reaction rate [11]. In addition, these metal cations promote the formation of DNAzyme structure as DNA is a negatively charged polyelectrolyte whose folding is strongly dependent on electrostatic [15]. Collectively, the overall reaction mechanism of metal cation-dependent RNA cleaving DNAzymes can be considered an evidence to support metal-assisted deprotonation of the $2^{\prime}$-hydroxyl located adjacent to the cleavage site 


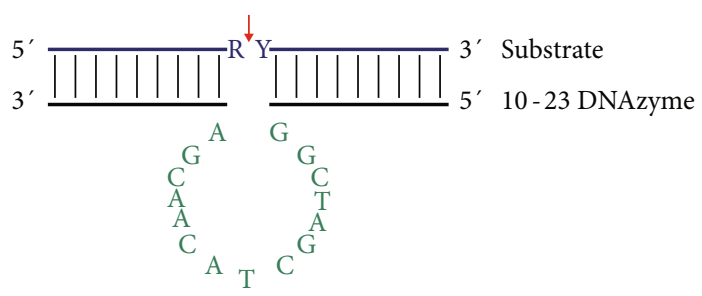

(a)

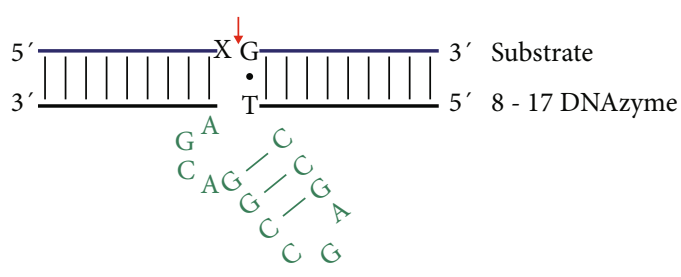

(b)

Figure 1: Structures of “10-23" (a) and "8-17” (b) DNAzymes. A, C, T, and G represent deoxyribonucleotides. R (A or G), Y (U or C), and X represent ribonucleotides. The red arrows indicate the cleavage site in the substrate strand.
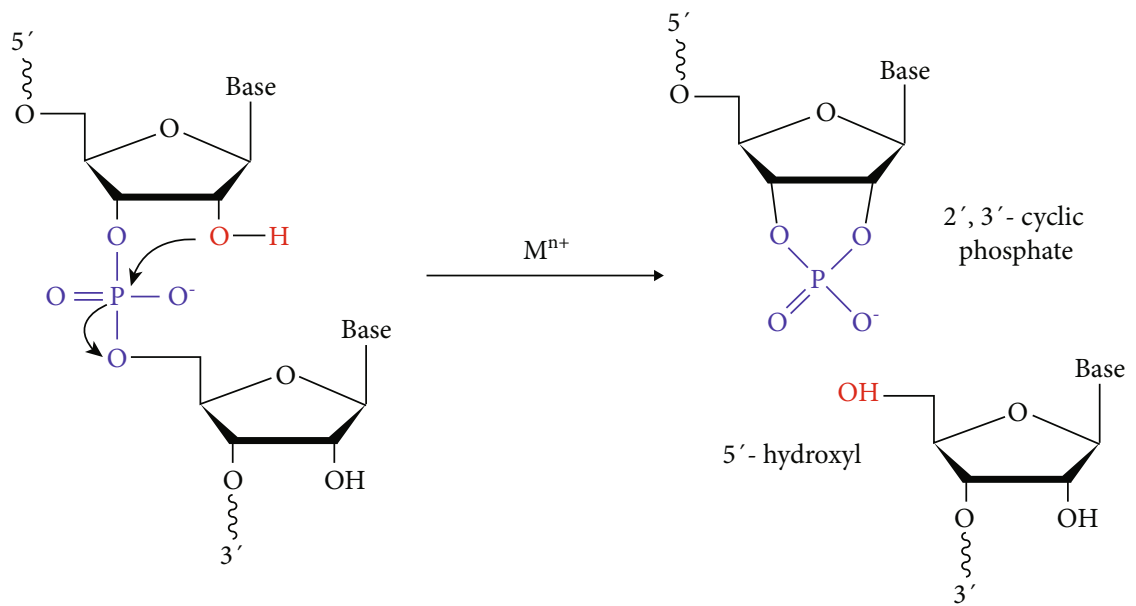

FIGURE 2: A generalized diagram showing the RNA cleavage catalyzed by a RNA cleaving DNAzyme forming a $2^{\prime}, 3^{\prime}$-cyclic phosphate and $5^{\prime}$-hydroxyl terminus, respectively.

[13]. This produces a nucleophilic $2^{\prime}$-oxyanion that attacks the adjacent phosphorus giving rise to intended cleavage products. The metal cation may participate in the chemical reaction either as a metal hydroxide that function as a general base to assist deprotonation of the $2^{\prime}$ - hydroxyl or as a Lewis acid that coordinates directly to $2^{\prime}$-hydroxyl enhancing its acidity [13].

The catalytic property of DNAzyme is particular; mismatch sequences in the binding arms or point mutations in the catalytic core make the DNAzyme catalytically inactive and can be used as control molecules when accessing the biological specificity of DNAzymes [9]. A variety of structural modifications are incorporated in order to enhance the stability and potency of DNAzymes. These include $3^{\prime}-3^{\prime}$ inverted nucleotide at the $3^{\prime}$ end, phosphorothioate linkages, and locked nucleic acids. Incorporating inverted thymidine at the $3^{\prime}$ terminus of the DNAzyme leading to a $3^{\prime}-3^{\prime}$ linkage increases the stability and resistance against $3^{\prime}$-exonuclease in human serum [16]. Phosphorothioate linkages in DNAzymes are characterized by the presence of a sulfur atom in one of the nonbridging phosphate oxygen atoms in the cleavage site [17]. These enhance the stability of DNAzymes by providing more resistance to endogenous nucleases. Phosphorothioate modifications are hardly applied in the field of DNAzymes as they are well known to cause nonspecific protein binding leading to toxicity [18]. Locked nucleic acids contain a $2^{\prime}-\mathrm{O}, 4-\mathrm{C}$ methylene bridge that locks sugar rings in a $\mathrm{C} 3^{\prime}$-endo confirmation. Incorporating locked nucleic acids into DNAzymes increases binding affinity, stability towards $3^{\prime}$-exonucleolytic degradation, and solubility and is considered an attractive strategy [9]. A concise summary of the advantages and disadvantages of these modifications is given in Table 1 .

Compared to other enzymes, DNAzyme shows some inherent advantages such as structural stability, accurate target cleavage without any immune response, and most negligible cytotoxicity. DNAzymes exert high specificity and can be easily modified or functionalized. Further, the synthesis of DNAzymes is cost-effective compared to other nucleic acid-based therapies [11].

\section{Application of DNAzymes in Cancer Research: Experimental Evidence}

Cancer is one of the leading life-threatening diseases in the world (https://www.who.int/news-room/fact-sheets/detail/ cancer). The development of efficient therapeutic strategies for cancer treatment is a fundamental aspect of cancer research. Treatment options at present, such as chemotherapy and radiation therapy, are not universally effective for 
TABLE 1: Advantages and disadvantages of different structural modifications used in DNAzymes.

\begin{tabular}{|c|c|c|c|c|}
\hline $\begin{array}{l}\text { Structural } \\
\text { modification }\end{array}$ & Advantages & Disadvantages & Key points & References \\
\hline $\begin{array}{l}3^{\prime}-3^{\prime} \text { inverted } \\
\text { nucleotide at the } \\
3^{\prime} \text { end }\end{array}$ & $\begin{array}{l}\text { Increase stability and enhance } \\
\text { catalytic activity }\end{array}$ & Slower product release rate & $\begin{array}{l}\text { Counteract the degradation by } 3^{\prime} \\
\text {-exonucleases }\end{array}$ & $\begin{array}{c}{[15,} \\
142-144]\end{array}$ \\
\hline $\begin{array}{l}\text { Phosphorothioate } \\
\text { linkages }\end{array}$ & Increase stability & $\begin{array}{l}\text { Affect cleavage efficiency, } \\
\text { toxicity, and immunologic } \\
\text { responsiveness and produce } \\
\text { sequence-independent effects }\end{array}$ & $\begin{array}{l}\text { Substitution of oxygen atoms with } \\
\text { sulfur atoms affects the DNAzyme } \\
\text { structure in a molecularity- } \\
\text { dependent manner } \\
\text { Counteract the degradation by } \\
\text { exonucleases }\end{array}$ & {$[142-144]$} \\
\hline $\begin{array}{l}\text { Locked nucleic } \\
\text { acids }\end{array}$ & $\begin{array}{c}\text { Increase affinity for complementary } \\
\text { sequence, increase stability, } \\
\text { solubility, easily automated } \\
\text { synthesis, and straightforward } \\
\text { cellular delivery }\end{array}$ & $\begin{array}{l}\text { Influence catalytic activity } \\
\text { and biological potency }\end{array}$ & $\begin{array}{l}\text { Increase in stability due to efficient } \\
\text { base stacking by adopting A-form } \\
\text { geometry and oxymethylene bridge } \\
\text { link between } 2^{\prime} \text { and } 4^{\prime} \text { carbon } \\
\text { atoms of a furanose ring } \\
\text { Charged backbone facilitating lucid } \\
\text { cellular transfection } \\
\text { A change in the charge distribution } \\
\text { of the minor groove wall furnish } \\
\text { solvation properties }\end{array}$ & $\begin{array}{c}{[142,143,} \\
145]\end{array}$ \\
\hline
\end{tabular}

all cancers [19]. Hence, there is a pertinent requirement to investigate novel therapeutic options.

Cancer is specified by the abnormal proliferation of any of the different kinds of cells in the body accompanied by metastasis, thereby giving rise to several distinct types of cancer that vary in their behaviour and response to treatment [20]. It involves complex genetic and epigenetic alterations that include mutations, chromosomal translocation or deletion, and downregulation or overexpression of tumor suppressor genes and protooncogenes [21]. These mechanisms contribute to activating genes that promote dysregulated cell cycling and/or inactivate apoptotic pathways [22] and drive the progressive transformation of normal human cells into highly malignant derivatives [10].

DNAzymes have exhibited great potential in downregulating cancer-associated genes. The anticancer DNAzymes make use of the hallmarks of cancer that include selfsufficiency in growth signals, insensitivity to growth inhibitory signals, tissue invasion, metastasis, sustained angiogenesis, evasion of apoptosis, and limitless replicative potential [23] to suppress tumor growth. Figure 3 comprises a schematic diagram showing different DNAzymes that have been explored so far to target various attributes of cancer whereas Table 2 summarizes the respective sequences of DNAzymes.

The subsequent sections will discuss the successful applications of DNAzymes in addressing the aforementioned cancer hallmarks. Tables 3 and 4 present an overview of in vitro and in vivo applications of DNAzymes in cancer treatment, respectively. Table 5 summarizes the clinically tested DNAzymes in cancer treatment so far.

3.1. DNAzymes Targeting Metastasis. The strategy of targeting metastasis has received increasing attention in cancer biology. Cancer metastasis is the process by which cancer cells spread to other parts of the body from the original tumor site [24]. It entails a series of steps, generally known as a metastasis cascade, which contributes to cancer severity. To complete the metastasis cascade, cancer cells must detach from the primary tumor, intravasate into the circulatory and lymphatic system, evade immune attack, extravasate at distant capillary beds, and invade and proliferate in distant organs [25]. The regulation of cell-cell and cell-matrix adhesions is crucial during metastasis.

Among the number of proteins involved in cancer metastasis, integrins play a major role and have been identified as an effective pharmacological target. Integrins are transmembrane cell adhesion receptors of $18 \alpha$ and $8 \beta$ subunits that combine to form about 24 different heterodimeric receptors [26]. $\beta 1$ is known to play a critical role in the migration, proliferation, metastasis, and angiogenesis of cancer [27].

Wiktorska et al. [28] formulated $\beta 1$ integrin- $\beta 1 \mathrm{DE}$ OME DNAzyme and transfected it into several colon carcinoma cell lines (CX1.1, HT29, LOVO, and LS180) and a prostate cancer cell line (PC-3). It was sobered that $\beta 1 \mathrm{DE}-$ OME treatment reduced the invasiveness of tested cells. Further, PC- 3 was more sensitive to $\beta 1 \mathrm{DE}-\mathrm{OME}$ compared to other cancer types [28]. Moreover, the inhibitory activity of $\beta 1$ integrin- $\beta 1 \mathrm{DE}$ was investigated in vivo using Matrigel plugs (BALB/c mice) and nude mice (BALB/cA nude (nu/-)-B6.Cg-Foxn $1^{\text {nu }}$ ) with solid carcinoma developed using PC-3 cells and CX1.1 cells [29]. Administration of $\beta 1 \mathrm{DE}$ effectively inhibited the neovascularization stimulated by bFGF added to Matrigel plugs. Further, intratumoral injection of $\beta 1 \mathrm{DE}$ produced a noticeable tumor size reduction in the CX1.1 and PC-3 xenografts within the 3 weeks of experiment duration [29]. In a parallel experiment, the efficacy of DNAzyme (DE $\beta 1)$ in inhibiting the expression of $\beta 1$ integrin was compared with siRNA (siRNA $\beta 1$ ) using HT29 and PC-3 cancer cells both in vitro and in vivo [30]. 


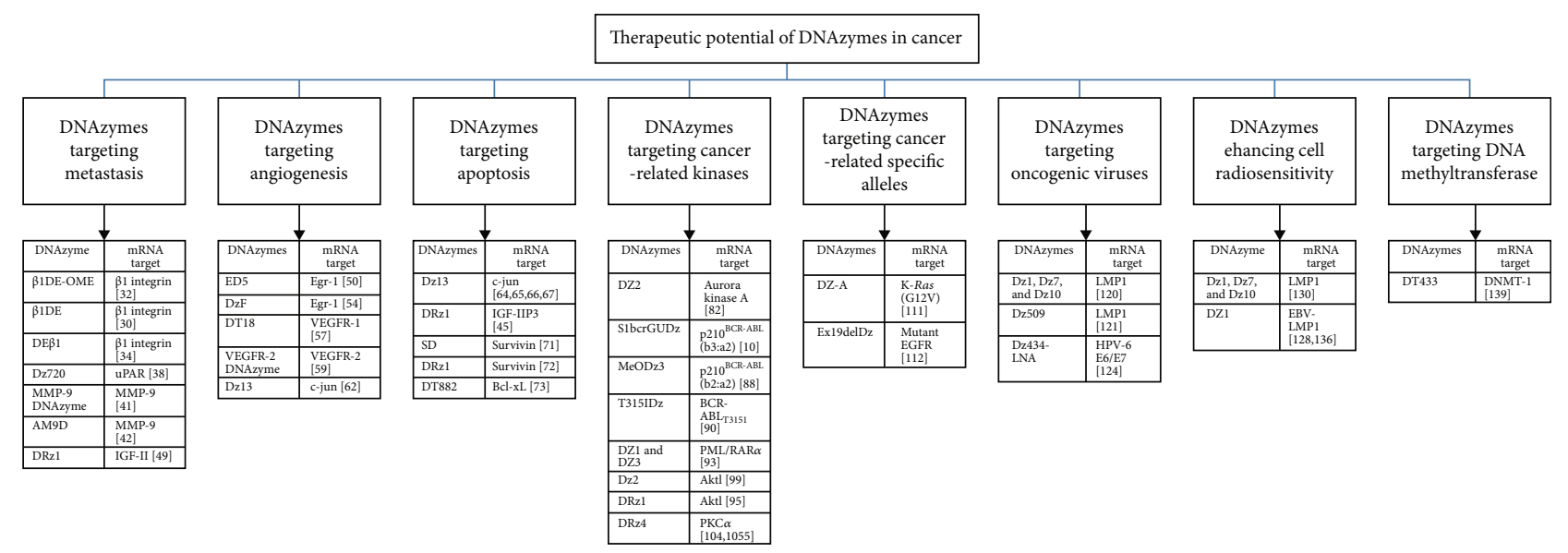

FIGURE 3: Schematic diagram showing the therapeutic potential of DNAzymes targeting various attributes of cancer.

Experimental results revealed that siRNA $\beta 1$ was slightly more efficient than $\mathrm{DE} \beta 1$ in the in vitro assay. However, $\mathrm{DE} \beta 1$ exhibited higher efficiency in blocking the tumor growth in vivo due to its resistance for degradation in extraand intracellular compartments when compared to that of siRNA [30].

A urokinase plasminogen activator system (uPA) is a serine protease group involved in multiple steps in cancer progression [31]. Elevated uPAR expression levels were observed in many types of cancer, including non-small-cell lung cancer (NSCLC) and colorectal cancer (CLC), leading to poor prognosis, early invasion, and metastasis [32]. uPA directs the catalysis of the formation of plasmin from plasminogen. Plasmin brings about the degradation of the extracellular matrix (ECM) and basement membrane, thereby facilitating the penetration of tumor cells to the ECM and basement membrane to metastasize [33].

de Bock et al. [34] designed three DNAzymes, Dz372, Dz483, and Dz720, against uPAR mRNA. Among them, two DNAzymes, Dz483 and Dz720, cleaved the target uPAR transcript with high efficacy and specificity in vitro. The ability of Dz720 and Dz483 to suppress uPAR mRNA expression was tested in a human osteosarcoma cell line (Saos-2). It was observed that Dz720 could inhibit the uPAR expression at both mRNA and protein levels. Saos- 2 cells treated with Dz720 brought about an inhibition in cell invasion due mainly to decreased invasion and partly reduced cell proliferation [34]. This system has shown a synergistic effect rather than only an additive effect [34].

Matrix metalloproteinases (MMPs) are members of the metzincin protease superfamily of zinc-endopeptidases which are involved in many biological processes such as degradation of ECM [35]. Among the 28 MMPs identified, MMP-9 is considered a potential biomarker whose overexpression can be seen in a wide array of tumors, including NSCLC and colorectal, cervical, and breast cancer [35]. MMP-9 degrades type IV collagen and contributes to tumor progression through invasion, metastasis, growth, and angiogenesis [36]. To determine the potential of DNAzymes as antimetastasis agents in the treatment of NSCLC by targeting the MMP-9 gene, Yang et al. [37] synthesized
MMP-9 DNAzyme and transfected it into an NSCLC cell line (A549). The DNAzyme downregulated the expression of MMP-9 at both mRNA and protein levels and inhibited cell proliferation, adhesion, migration, and invasive capacity in vitro. MMP-9-AM9D DNAzyme has also been tested to determine its efficacy as an antitumor agent for breast cancer therapy both in vitro and in vivo. Upon transfection into a human breast cancer cell line (MDA-MB-231), the DNAzyme downregulated the MMP-9 mRNA expression, concomitantly inhibiting the invasive behavior of MDA-MB231 cells in vitro. MMTV-PyMT transgenic breast cancer mouse model was used to figure out the capacity of AM9D as an inhibitor of MMP-9 in vivo [38]. Broad-spectrum MMP inhibitor, Galardin/GM6001, reduced primary mammary tumor growth and lung metastasis in the MMTVPyMT model. Compared with the broad-spectrum inhibitor, GM6001 [39], AM9D treatment has downregulated the MMP-9 without affecting the expression of other members of the MMP family.

Derangement of the insulin-like growth factor (IGF) signaling pathway, predominantly at the level of IGF-II availability, is implicated in many types of cancers [40]. IGF-II is a fetal growth protein and an essential proangiogenic factor [41]. The human IGF-II gene contains four promoters (P1-P4) [42], out of which P1 is active and P2-P4 are decreased or completely deactivated in the adult liver [43]. Reactivation of the main active promoters in fetal development, such as P3, contributes to increased levels of IGF-II in hepatocellular carcinoma (HCC) cells [41]. IGF-II directly promotes angiogenesis and indirectly promotes the formation of liver cancer blood vessels, thereby contributing to tumor progression. A variety of liver cancer cell lines secrete IGF-II through an autocrine or paracrine mechanism [44]. In their study, Zhang et al. [45] evaluated DRz1 to determine its effect on inhibiting the invasion, motility, and migration of an HCC cell line (SMMC-7721). Treatment with DRz1 downregulated the IGF-II expression at both mRNA and protein levels and inhibited the invasion, motility, and migration of SMMC-7721 cells. Also, DRz1 reduced the adhesion of tested cells to ECM proteins such as fibronectin and laminin and human fibroblast cells. Further, DRz1 
TABLE 2: Respective sequences of DNAzymes.

\begin{tabular}{|c|c|}
\hline DNAzyme & DNAzyme sequence \\
\hline$\beta 1 \mathrm{DE}-\mathrm{OME}$ & 5' -CAAGGTGAGGGCTAGCTACAACGAAATAGAAG-3' [28] \\
\hline $\mathrm{DE} \beta 1$ & $5^{\prime}$-CAAGGTGAGGGCTAGCTACAACGAAATAGAAG-3' [30] \\
\hline Dz720 & $5^{\prime}$-GAGCATCCAGGCTAGCTACAACGAGGGTGCTGT-3' [34] \\
\hline MMP-9 DNAzyme & $5^{\prime}$-AGGCGCCCAGGCTAGCTACA ACGACTCCGCGGC-3' [37] \\
\hline AM9D & $5^{\prime}$-GTGGTGCCAGGCTAGC TACAACGATTGAGGTCG-3' [38] \\
\hline DRz1 & 5'-GATTCCCAGGCTAGCTACAAC GATGGTGTCT-3' [45] \\
\hline ED5 & 5'-CCGCTGCCAGGCTAGCTACAACGACCCGGACGTTI-3' [46] \\
\hline $\mathrm{DzF}$ & 5'-GCGGGGACAGGCT AGCTACAACGACAGCTGCATTI-3' [50] \\
\hline DT18 & $5^{\prime}$-AGAGTGAGGCTAGCTACAACGAGGAGT-3' $[53]$ \\
\hline VEGFR-2 DNAzyme & 5'-TGCTCTCCAGGCTAGCTACAACGACCTGCACCT-3' [55] \\
\hline Dz13 & $5^{\prime}$-CGGGAGGAAGGCTAGCTACAACGAGAGGCGTTG-TI- $3^{\prime}[58,60-63]$ \\
\hline SD & 5'-CCTCGGCCA GGC TAG CTA CAA CGA CCGCTCCGG-3' [67] \\
\hline DRz1 & $5^{\prime}$-GCCTCGGTCCGCTCCG-3' $[68]$ \\
\hline DT882 & $5^{\prime}$-TTTTTATAAGGCTAGCTACAACGAAGGGATGGG-3' [69] \\
\hline DZ2 & 5' -TTAACAGGGGCTAGCTAC AACGACCTGAAAT-3' [78] \\
\hline SibcrGUDz & $5^{\prime}$-AGGGCTTTTGAAGGCTAGCTACAACGATCTGCT-3' $[10]$ \\
\hline $\mathrm{MeODz3}$ & 5'-CTGAAGGGGGCTAGCGTACAACGATTCTTCCCT-3' [84] \\
\hline T315IDz & 5' -CATGAACTCAACCGTAGCTACAACGAGATGATATAG-3' [86] \\
\hline DZ1 & 5'-CTCAATGGGGCTAGCTACAACGATGCCTCCC-3' [89] \\
\hline DZ3 & 5' -CTCAATGGGGCTAGGCTACAACGATGCCTCCC-3' [89] \\
\hline Dz2 & $5^{\prime}$-TGGTCCACAGGCTAGCTACAACGACCTGCGGCC-3 ${ }^{\prime}$ [95] \\
\hline DRz1 & 5'-GTCGTCCAGGCTAGCTACAACGAGGGGTACC-3' [91] \\
\hline DRz4 & $5^{\prime}$-GTCAGCCAGGCTAGCTACAACGAGGTCCCCC-3' $[100,101]$ \\
\hline DZ-A & 5'-CTACGCCAAGGCTAGCTACAACGAAGCTCCAACT-3' [107] \\
\hline Ex19delDZ & 5'-GCTTTCGGTGTGGCTAGCTACAACGAGTTTTGATAG-3' [108] \\
\hline Dz1 & $5^{\prime}$-GCAAAGGAAGGCTAGCTACAACGAAGAGGACAA-3' $[116,126]$ \\
\hline Dz7 & $5^{\prime}$-AGGGAGTCAGGCTAGCTACAACGACGTGGTGGT-3' $[116,126]$ \\
\hline Dz10 & $5^{\prime}$-CGTGTTCCAGGCTAGCTACAACGAGGTCAGGGT-3' $[116,126]$ \\
\hline Dz509 & 5'-CAAAGGAGAGGCTAGCTACAACGACAACCAATA-3' [117] \\
\hline Dz434-LNA & $5^{\prime}$-TTCAGGAGGCTAGCTACAACGAACAGTGG-3' [120] \\
\hline DZ1 & $5^{\prime}$-GCAAAGGAAGGCTAGCTACAACGAAGAGGACAA-3' $[124,132]$ \\
\hline DT433 & 5'-GGTTGGTGA GGCTAGCTACAACGA GGTTGTGCT-3' [135] \\
\hline
\end{tabular}

downregulated the expression of vascular endothelial growth factor (VEGF) and MMP-9 at both mRNA and protein levels, thereby inhibiting the invasion and motility of SMMC-7721 cells [45].

3.2. DNAzymes Targeting Angiogenesis. Angiogenesis is the process by which new blood vessels are formed from the preexisting vasculature. Cancer cells, albeit malignant, depend on blood vasculature for oxygen, nutrients, and waste removal similar to normal cells, and therefore, angiogenesis is imperative in tumor progression [46]. Angiogenesis is under the regulation of both activator and inhibitor molecules, and the expression levels of these angiogenic factors determine the aggression of tumor cells [47].
Early growth response-1 (Egr-1) is a member of the family of $\mathrm{Cys}_{2}$-His $\mathrm{H}_{2}$-type zinc finger transcription factors containing a highly conserved DNA-binding domain that binds to GC-rich recognition motifs [48]. Egr-1 regulates cell growth and differentiation upon the activation by extracellular agonists such as growth factors and cytokines and environmental stresses such as radiation, vascular injury, fluid shear stress, and hypoxia [46]. It is expressed in several different kinds of breast carcinoma cells, for instance, MCF7 and MDA-MB-231 [49]. It is associated with transformed growth, multidrug resistance-1 (MDR-1) gene transcription, and antiestrogen responsiveness in MCF-7 cells [50]. Assembling both in vitro and in vivo analyses, Fahmy et al. [46] identified the mandatory role played by Egr-1 in 
TABLE 3: In vitro applications of DNAzymes in cancer treatment.

\begin{tabular}{|c|c|c|c|c|c|c|}
\hline $\begin{array}{l}\text { Carcinoma cell } \\
\text { line/s }\end{array}$ & $\begin{array}{c}\text { mRNA } \\
\text { target }\end{array}$ & DNAzyme & Modifications & Delivery system & Outcome & Reference \\
\hline $\begin{array}{l}\text { CX1.1, HT29, } \\
\text { LOVO, LS180, } \\
\text { and PC-3 }\end{array}$ & $\begin{array}{c}\beta 1 \\
\text { integrin }\end{array}$ & $\begin{array}{l}\beta 1 \mathrm{DE}- \\
\mathrm{OME}\end{array}$ & $\begin{array}{l}2^{\prime} \text {-O-Methyl modifications } \\
\text { at both the } 5^{\prime} \text { and } 3^{\prime} \text { ends }\end{array}$ & $\begin{array}{c}\text { LipofectAMINE }{ }^{\mathrm{TM}} \\
\text { reagent }\left(\mathrm{Giboo} \mathrm{BRL}^{\circledR}\right) .\end{array}$ & $\begin{array}{l}\text { Inhibition of adhesion and } \\
\text { invasion }\end{array}$ & {$[28]$} \\
\hline PC-3 and HT29 & $\begin{array}{c}\beta 1 \\
\text { integrin }\end{array}$ & $\mathrm{DE} \beta 1$ & $\begin{array}{l}2^{\prime} \text {-O-methyl modifications } \\
\text { at both the } 5^{\prime} \text { and } 3^{\prime} \text { ends }\end{array}$ & $\begin{array}{c}\text { LipofectAMINE }^{\mathrm{TM}} \\
\text { reagent }\end{array}$ & $\begin{array}{l}\text { Inhibition of adhesion and } \\
\text { invasion }\end{array}$ & {$[30]$} \\
\hline Saos-2 & uPAR & Dz720 & $\begin{array}{c}\text { Phosphorothioate } \\
\text { modifications in the last } \\
\text { three nucleotides at both } \\
\text { ends }\end{array}$ & $\begin{array}{l}\text { Lipofectamine } 2000 \\
\quad \text { (Invitrogen) }\end{array}$ & $\begin{array}{l}\text { Inhibition of invasion and } \\
\text { metastasis }\end{array}$ & {$[34]$} \\
\hline A549 & MMP-9 & $\begin{array}{l}\text { MMP-9 } \\
\text { DNAzyme }\end{array}$ & $\begin{array}{c}\text { Phosphorothioate } \\
\text { modification at the first and } \\
\text { last two phosphodiester } \\
\text { linkages }\end{array}$ & $\begin{array}{l}\text { Oligofectamine } \\
\text { (Invitrogen) }\end{array}$ & $\begin{array}{l}\text { Inhibition of cell } \\
\text { proliferation, adhesion, } \\
\text { migration, and invasion }\end{array}$ & {$[37]$} \\
\hline MDA-MB-231 & MMP-9 & AM9D & - & $\begin{array}{l}\text { Lipofectamine } 2000 \\
\quad \text { (Invitrogen) }\end{array}$ & Inhibition of invasion & {$[42]$} \\
\hline SMMC-7721 & IGF-II & DRz1 & $\begin{array}{l}\text { Inverted thymidine at the } 3^{\prime} \\
\text { position }\end{array}$ & Lipofectamine 2000 & $\begin{array}{l}\text { Inhibition of invasion, } \\
\text { motility, migration, and } \\
\text { adhesion }\end{array}$ & {$[45]$} \\
\hline $\begin{array}{l}\text { PC-3, MDA- } \\
\text { MB-231, SaOS- } \\
\text { 2, 143B, SJSA-1, } \\
\text { G292, and } \\
\text { SW872 }\end{array}$ & c-jun & Dz13 & $\begin{array}{l}\text { Inverted thymidine at the } 3^{\prime} \\
\text { position }\end{array}$ & FuGENE6 (Roche) & Induction of apoptosis & {$[60]$} \\
\hline $\begin{array}{l}\text { SMMC-7721, } \\
\text { HepG2, and } \\
\text { Huh7 }\end{array}$ & $\begin{array}{l}\text { IGF- } \\
\text { IIP3 }\end{array}$ & DRz1 & $\begin{array}{l}\text { Inverted thymidine at the } 3^{\prime} \\
\text { position }\end{array}$ & $\begin{array}{l}\text { Lipofectamine }^{\circledR} 2000 \\
\text { (Invitrogen) }\end{array}$ & $\begin{array}{l}\text { Inhibition of cell proliferation } \\
\text { and induction of apoptosis }\end{array}$ & {$[41]$} \\
\hline PANC-1 & Survivin & SD & $\begin{array}{c}5^{\prime} \text { phosphorothioate } \\
\text { linkage and } 3^{\prime} \text { SPACER-C3 } \\
\text { cap }\end{array}$ & $\begin{array}{l}\text { Oligofectamine } \\
\text { (Invitrogen) }\end{array}$ & $\begin{array}{l}\text { Induction of apoptosis and } \\
\text { inhibition of cell proliferation }\end{array}$ & {$[67]$} \\
\hline MCF-7 & Survivin & DRz1 & - & $\begin{array}{l}\text { Lipofectamine } 2000 \\
\quad \text { (Invitrogen) }\end{array}$ & $\begin{array}{l}\text { Inhibition of cell proliferation } \\
\text { and migration and induction } \\
\text { of apoptosis }\end{array}$ & {$[68]$} \\
\hline $\begin{array}{l}\text { PC-3, T24, } \\
\text { A549, MDA- } \\
\text { MD-231, B9-58, } \\
\text { and HCT116 }\end{array}$ & Bcl-xL & DT882 & $\begin{array}{l}1,3 \text {, or } 5 \text { phosphorothioate } \\
\text { modifications at both ends }\end{array}$ & $\begin{array}{l}\text { Tetra meso (4- } \\
\text { methylpyridyl) } \\
\text { porphyrin (TMP) }\end{array}$ & $\begin{array}{l}\text { Induction of apoptosis and } \\
\text { chemosensitivity }\end{array}$ & [69] \\
\hline PC-3 & $\begin{array}{r}\text { Aurora } \\
\text { kinase A }\end{array}$ & $\mathrm{DZ2}$ & - & FuGENE 6 (Roche) & $\begin{array}{l}\text { Suppression of cell growth, } \\
\text { inhibition of cell cycle } \\
\text { progression, induction of cell } \\
\text { apoptosis, and attenuation of } \\
\text { cell migration }\end{array}$ & {$[78]$} \\
\hline K562 & $\begin{array}{l}\mathrm{p} 210^{\mathrm{BCR}-} \\
\mathrm{ABL} \\
(\mathrm{b} 3: \mathrm{a} 2)\end{array}$ & S1bcrGUDz & $\begin{array}{l}\text { Phosphorothioate } \\
\text { modifications in the first } \\
\text { two bases at } 5^{\prime} \text { end and the } \\
\text { last two bases at } 3^{\prime} \text { end }\end{array}$ & Liposome (GS2888) & Inhibition of cell growth & {$[10]$} \\
\hline BV173 & $\begin{array}{l}\mathrm{p} 210^{\mathrm{BCR}-} \\
\mathrm{ABL} \\
(\mathrm{b} 2: \mathrm{a} 2)\end{array}$ & MeODz3 & $\begin{array}{l}2^{\prime} \text {-O-Methyl modifications } \\
\text { at both ends }\end{array}$ & Lipofectin & Induction of apoptosis & {$[88]$} \\
\hline $\begin{array}{l}\mathrm{BaF} 3 / \mathrm{BCR}- \\
\mathrm{ABL}_{\mathrm{T} 315 \mathrm{I}}\end{array}$ & $\begin{array}{l}\text { BCR- } \\
\mathrm{ABL}_{\mathrm{T} 315 \mathrm{I}}\end{array}$ & T315IDz & $\begin{array}{l}\text { Phosphorothioate } \\
\text { modifications in the first } \\
\text { two bases at } 5^{\prime} \text { end and the } \\
\text { last two bases at } 3^{\prime} \text { end }\end{array}$ & $\begin{array}{l}\text { Cells were transfected } \\
\text { by electroporation } \\
\text { using the Neon } \\
\text { Transfection System } \\
\text { (Invitrogen) }\end{array}$ & $\begin{array}{l}\text { Inhibition of cell viability, } \\
\text { suppression of cell growth } \\
\text { rate, induction of apoptosis, } \\
\text { and chemosensitization }\end{array}$ & {$[86]$} \\
\hline NB4 & & & - & & & [89] \\
\hline
\end{tabular}


TABLE 3: Continued.

\begin{tabular}{|c|c|c|c|c|c|c|}
\hline $\begin{array}{l}\text { Carcinoma cell } \\
\text { line/s }\end{array}$ & $\begin{array}{l}\text { mRNA } \\
\text { target }\end{array}$ & DNAzyme & Modifications & Delivery system & Outcome & Reference \\
\hline & $\begin{array}{l}\text { PML/ } \\
\text { RAR } \alpha \\
\text { mRNA }\end{array}$ & $\begin{array}{l}\text { DZ1 and } \\
\text { DZ3 }\end{array}$ & & $\begin{array}{c}\text { Dioleoyl-3- } \\
\text { trimethylammonium } \\
\text { propane (DOTAP) } \\
\text { liposome (Roche) }\end{array}$ & $\begin{array}{c}\text { Inhibition of cell } \\
\text { proliferation, reduction of } \\
\text { cell viability, and induction of } \\
\text { apoptosis }\end{array}$ & \\
\hline CNE1-LMP1 & Akt1 & $\mathrm{Dz} 2$ & $\begin{array}{c}\text { Phosphorothioate } \\
\text { modification at the first and } \\
\text { last two phosphodiester } \\
\text { linkages }\end{array}$ & $\begin{array}{l}\text { Oligofectamine } \\
\text { (Invitrogen) }\end{array}$ & $\begin{array}{l}\text { Inhibition of cell proliferation } \\
\text { and induction of apoptosis }\end{array}$ & [99] \\
\hline SW597 & Akt1 & DRz1 & $\begin{array}{c}5^{\prime} \text { phosphorothioate } \\
\text { linkage and } 3^{\prime} \mathrm{CPG} \text {-amine } \\
\text { C7 cap }\end{array}$ & Lipofectamine 2000 & $\begin{array}{l}\text { Inhibition of cell } \\
\text { proliferation, induction of } \\
\text { apoptosis, and inhibition of } \\
\text { invasion }\end{array}$ & [91] \\
\hline T98G & $\mathrm{PKC} \alpha$ & DRz4 & $\begin{array}{l}\text { Phosphorothioate } \\
\text { modifications at the } \\
\text { antisense arms and within } \\
\text { the pyrimidine residues of } \\
\text { the catalytic core }\end{array}$ & $\begin{array}{c}\text { Dioleoyl-3- } \\
\text { trimethylammonium } \\
\text { propane (DOTAP) } \\
\text { liposome }\end{array}$ & $\begin{array}{l}\text { Inhibition of cell proliferation } \\
\text { and induction of apoptosis }\end{array}$ & {$[100]$} \\
\hline SW480 & $K$-Ras & $\mathrm{DZ}-\mathrm{A}$ & $\begin{array}{c}\text { Phosphorothioate } \\
\text { modifications in the last } \\
\text { three nucleotides at the } 3^{\prime} \\
\text { end }\end{array}$ & Lipofectin (Invitrogen) & $\begin{array}{l}\text { Sensitization to chemo- and } \\
\text { radiation therapies }\end{array}$ & {$[107]$} \\
\hline PC9/GR & $\begin{array}{l}\text { Mutant } \\
\text { EGFR }\end{array}$ & Ex19delDZ & - & $\begin{array}{l}\text { Lipofectamine } 2000 \\
\text { (Invitrogen) }\end{array}$ & $\begin{array}{l}\text { Reduction in cell viability, } \\
\text { suppression of cell } \\
\text { proliferation, and induction } \\
\text { of apoptosis }\end{array}$ & [108] \\
\hline B95-8 & LMP1 & $\begin{array}{l}\mathrm{Dz} 1, \mathrm{Dz} 7 \\
\text { and Dz10 }\end{array}$ & $\begin{array}{l}\text { Two phosphorothioate } \\
\text { modifications on both arms }\end{array}$ & $\begin{array}{l}\text { Tetra meso (4- } \\
\text { methylpyridyl) } \\
\text { porphyrin (TMP) }\end{array}$ & $\begin{array}{l}\text { Inhibition of cell proliferation } \\
\text { and induction of apoptosis }\end{array}$ & {$[116]$} \\
\hline CNE1-LMP1 & LMP1 & $\begin{array}{l}\text { Dz1, Dz7, } \\
\text { and Dz10 }\end{array}$ & $\begin{array}{l}\text { Two phosphorothioate } \\
\text { modifications on both arms }\end{array}$ & $\begin{array}{l}\text { Tetra meso (4- } \\
\text { methylpyridyl) } \\
\text { porphyrin (TMP) }\end{array}$ & $\begin{array}{l}\text { Inhibition of cell } \\
\text { proliferation, induction of } \\
\text { apoptosis, and } \\
\text { radiosensitization }\end{array}$ & {$[126]$} \\
\hline $\mathrm{SiHa}$ & $\begin{array}{l}\mathrm{HPV}-16 \\
\mathrm{E} 6 / \mathrm{E} 7\end{array}$ & $\begin{array}{l}\text { Dz434- } \\
\text { LNA }\end{array}$ & $\begin{array}{l}\text { Locked nucleic acid (LNA) } \\
\text { modifications }\end{array}$ & Lipofectin (Invitrogen) & $\begin{array}{l}\text { Inhibition of cell proliferation } \\
\text { and induction of apoptosis }\end{array}$ & [120] \\
\hline $\mathrm{T} 24$ & DNMT1 & DT433 & - & Lipofectamine & Inhibition of cell proliferation & {$[135]$} \\
\hline
\end{tabular}

proliferation, migration, and neovascularization of microvascular endothelial cells. Based on that, Egr-1-ED5 DNAzyme was exploited in deciding its capacity against tumor growth and angiogenesis in vivo. Administration of ED5 into athymic nude mice resulted in a profound reduction in tumor growth without affecting body weight, wound healing, hemostasis, and reproduction. It was identified that ED5 inhibited the MCF-7 tumor growth by blocking host angiogenesis. Both Egr-1 and fibroblast growth factor-2 (FGF-2) expression levels were substantially low in MCF-7 tumors treated with ED5. Administration of FGF-2 produced a robust tumor regrowth suggesting the reversible and FGF2-mediated inhibition of endothelial growth and tumor angiogenesis by ED5 [46].

Egr-1-DzF is another DNAzyme which produced a profound sequence-specific inhibition of solid breast carcinoma growth in vivo. The ability of Egr-1 DNAzymes to attenuate angiogenesis suggests the emerging feasibility of smallmolecule gene-targeting agents as cancer therapeutics [50].
VEGF is identified as an endothelial cell-specific mitogen produced by many cell types, including tumor cells, macrophages, platelets, keratinocytes, and renal mesangial [51]. VEGF-A is one of the five members of the mammalian VEGF family regulating angiogenesis by interacting with two major tyrosine kinase receptors, namely, VEGFR-1 (FLT-1) and VEGFR-2 (KDR/ FLK-1) [52]. In relation to the surrounding normal tissue vasculature, VEGFR-1 and VEGFR-2 have upregulated tumor-associated endothelial cells (ECs) in various tumors [53]. VEGFR-2 induces vascular permeability, proliferation, differentiation, survival, and migration of ECs and drives VEGF-mediated angiogenesis [54]. The VEGF/VEGFR signaling pathway is usually upregulated in many types of cancers, and therefore, therapeutic paradigms targeting VEGF/VEGFR are of prime importance.

Shen et al. [53] conducted a comprehensive study to determine the potentiality of DNAzymes targeting VEGFR1 both in vitro and in vivo as cancer therapeutics. Out of 
TABLE 4: In vivo applications of DNAzymes in cancer treatment.

\begin{tabular}{|c|c|c|c|c|c|c|}
\hline $\begin{array}{l}\text { mRNA } \\
\text { target }\end{array}$ & DNAzyme & Animal & Xenograft & Dose regime & Outcome & Reference \\
\hline $\begin{array}{l}\beta 1 \\
\text { integrin }\end{array}$ & $\beta 1 \mathrm{DE}$ & $\begin{array}{l}\text { BALB/cA nude } \\
(\mathrm{nu}-/-)-\mathrm{B} 6 . \mathrm{Cg}- \\
\text { Foxn } 1^{\text {nu }} \text { mice }\end{array}$ & $\begin{array}{l}\text { PC-3 and } \\
\text { CX1.1 }\end{array}$ & $\begin{array}{l}\text { Intratumoral administration of } 1.25 \mu \mathrm{g} \text { of } \\
\beta 1 \mathrm{DE} \text { every second day after the tumor } \\
\text { volume reached } 150 \mathrm{~mm}^{3} \text { for three weeks }\end{array}$ & $\begin{array}{l}\text { Inhibition of solid tumor } \\
\text { growth }\end{array}$ & {$[26]$} \\
\hline $\begin{array}{l}\beta 1 \\
\text { integrin }\end{array}$ & $\mathrm{DE} \beta 1$ & $\begin{array}{l}\text { BALB/cA nude } \\
(\text { nu-/-)-B6.Cg- } \\
\text { Foxn1 } 1^{\text {nu }} \text { mice }\end{array}$ & $\begin{array}{l}\text { PC-3 and } \\
\text { HT29 }\end{array}$ & $\begin{array}{l}\text { Intratumoral administration of } 1.25 \mu \mathrm{g} \text { of } \\
\mathrm{DE} \beta 1 \text { per tumor eight times every second } \\
\text { day after the tumor volume reached } 80 \text { - } \\
\qquad 150 \mathrm{~mm}^{3}\end{array}$ & $\begin{array}{l}\text { Inhibition of solid tumor } \\
\text { growth }\end{array}$ & {$[30]$} \\
\hline MMP-9 & AM9D & $\begin{array}{l}\text { MMTV-PyMT } \\
\text { transgenic mice }\end{array}$ & $\begin{array}{l}\text { Breast } \\
\text { tumor }\end{array}$ & $\begin{array}{c}\text { When tumors were at early palpable size, } \\
\text { intratumoral administration of } 10 \text { or } \\
25 \mu \mathrm{g} \text { of AM9D once per week for four } \\
\text { weeks }\end{array}$ & $\begin{array}{c}39.5 \% \text { and } 50 \% \text { reduction in } \\
\text { tumor size, respectively, } 77 \% \\
\text { reduction in MMP-9 mRNA } \\
\text { level }\end{array}$ & {$[38]$} \\
\hline \multirow[t]{2}{*}{ Egr-1 } & ED5 & $\begin{array}{l}\text { Athymic Balb/c } \\
\text { nude mice }\end{array}$ & MCF-7 & $\begin{array}{l}\text { Intratumoral administration of } 20 \mu \mathrm{L} \text { of } \\
\text { ED5 with } 1 \mu \mathrm{L} \text { of FuGENE6 twice a week }\end{array}$ & $\begin{array}{l}\text { Inhibition of solid tumor } \\
\text { growth }\end{array}$ & {$[46]$} \\
\hline & $\mathrm{DzF}$ & $\mathrm{Balb} / \mathrm{c}$ nude mice & $\begin{array}{l}\text { MDA- } \\
\text { MB-231 }\end{array}$ & $\begin{array}{c}\text { When the tumors were palpable, } \\
\text { intratumoral administration of } 10 \mu \mathrm{g} \text { of } \\
\text { DzF twice per week in an injectate volume } \\
\text { of } 10 \mu \mathrm{L}\end{array}$ & $\begin{array}{l}\text { Inhibition of solid tumor } \\
\text { growth }\end{array}$ & {$[50]$} \\
\hline $\begin{array}{l}\text { VEGFR- } \\
1\end{array}$ & DT18 & $\begin{array}{l}\text { Athymic nude } \\
\text { mice }\end{array}$ & $\begin{array}{l}\text { CNE1- } \\
\text { LMP1 }\end{array}$ & $\begin{array}{l}\text { When the tumor volume reached 60- } \\
100 \mathrm{~mm}^{3} \text {, intratumoral administration of } \\
100 \mu \mathrm{g} \text { of DT18 with } 3 \mu \mathrm{L} \text { of Fugene6, } \\
\text { twice a week }\end{array}$ & $\begin{array}{l}\text { Suppression of tumor } \\
\text { growth, changes in tumor } \\
\text { vasculature and vessel } \\
\text { permeability }\end{array}$ & {$[53]$} \\
\hline $\begin{array}{l}\text { VEGFR- } \\
2\end{array}$ & $\begin{array}{l}\text { VEGFR2 } \\
\text { DNAzyme }\end{array}$ & $\begin{array}{l}\text { Athymic nude } \\
\text { mice }\end{array}$ & $\begin{array}{l}\text { MDA- } \\
\text { MB-435 }\end{array}$ & $\begin{array}{l}\text { When the tumor was visible, four } \\
\text { intratumoral administrations consisting } \\
\text { his-lys polymer with } 2.9 \mu \mathrm{g} \text { of DNAzyme }\end{array}$ & $\begin{array}{l}75 \% \text { reduction in tumor } \\
\text { growth, reduction in blood } \\
\text { vessel density, cell death in } \\
\text { tumor periphery }\end{array}$ & {$[59]$} \\
\hline \multirow[t]{4}{*}{ c-jun } & Dz13 & C57BL/J6 mice & B16F10 & $\begin{array}{l}\text { Commencement of the experiment, } \\
\text { subcutaneous administration of } 200 \mu \mathrm{L} \text { of } \\
\text { vehicle containing } 750 \mu \mathrm{g} \text { of Dz13 and } \\
2.5 \mu \mathrm{L} \text { of FuGENE6 twice per week }\end{array}$ & $\begin{array}{l}60 \% \text { reduction in tumor } \\
\text { growth, inhibition of tumor } \\
\text { vascular density }\end{array}$ & {$[58]$} \\
\hline & & $\mathrm{Balb} / \mathrm{c}$ nude mice & $\mathrm{SaOS}-2$ & $\begin{array}{l}\text { When the tumors were palpable, } \\
\text { intratibial administration of Dz13 at } \\
0.8 \mu \mathrm{M} \text { and caspase-2siRNA at } 4 \mu \mathrm{M} \text { in } \\
50 \% \text { Matrigel }\end{array}$ & $\begin{array}{l}\text { Induction of caspase-2 } \\
\text { expression }\end{array}$ & {$[60]$} \\
\hline & & Mice & SW872 & $\begin{array}{c}\text { Commencement of the experiment, } \\
\text { intramuscular administration of } \\
\text { Dz13+FuGENE6 at an oligonucleotide } \\
\text { concentration of } 0.4 \mu \mathrm{M} \text { into the hind } \\
\text { limb }\end{array}$ & Inhibition of tumor growth & {$[61]$} \\
\hline & & $\begin{array}{l}\text { Severe-combined } \\
\text { immunodeficient } \\
\text { and } \mathrm{C} 3 \mathrm{H} / \mathrm{Hen} \\
\text { mice }\end{array}$ & T79 & $\begin{array}{c}\text { After } 15-20 \text { days of dermal implantation, } \\
\text { intratumoral administration of } 20 \text { and } \\
40 \mu \mathrm{g} \text { of Dz13 with DOTAP and DOPE } \\
\text { twice per week }\end{array}$ & $\begin{array}{l}\text { Inhibition of tumor growth } \\
\text { and suppression of } \\
\text { neovascularization }\end{array}$ & {$[66]$} \\
\hline Bcl-xL & DT882 & $\begin{array}{l}\text { Balb/c athymic } \\
\text { nude mice }\end{array}$ & PC3 & $\begin{array}{l}\text { When tumors reached } 100-200 \mathrm{~mm}^{3} \text {, a } \\
\text { dose rate of } 12.5 \mathrm{mg} / \mathrm{kg} / \mathrm{d} \text { of saline } \\
\text { solution containing DT } 882 \text { over } 14 \text { days } \\
\text { via a ALZET osmotic pump } \\
\text { (BioScientific) }\end{array}$ & $\begin{array}{l}\text { Inhibition of tumor growth } \\
\text { and chemosensitization }\end{array}$ & [69] \\
\hline $\begin{array}{l}\text { Aurora } \\
\text { kinase A }\end{array}$ & $\mathrm{DZ2}$ & $\mathrm{Balb} / \mathrm{c}$ nude mice & PC3 & $\begin{array}{l}\text { When the tumor reached about } 65 \mathrm{~mm}^{3} \text {, } \\
\text { intratumoral administration of } 8 \mu \mathrm{g} \text { of } \\
\text { DZ2 daily for } 14 \text { days }\end{array}$ & Inhibition of tumor growth & {$[78]$} \\
\hline Akt1 & Dz2 & Balb/c nude mice & $\begin{array}{l}\text { CNE1- } \\
\text { LMP1 }\end{array}$ & $\begin{array}{c}\text { When the tumor volume reached } 60- \\
100 \mathrm{~mm}^{3} \text {, intratumoral administration of } \\
10 \mu \mathrm{g} \text { of Dz2 with } 3 \mu \mathrm{L} \text { of FuGENE6 twice } \\
\text { per week }\end{array}$ & Inhibition of tumor growth. & {$[95]$} \\
\hline $\operatorname{PKC} \alpha$ & DRz4 & & $\mathrm{BT}_{4} \mathrm{C}$ & & & {$[101]$} \\
\hline
\end{tabular}


TABLE 4: Continued.

\begin{tabular}{|c|c|c|c|c|c|c|}
\hline $\begin{array}{l}\text { mRNA } \\
\text { target }\end{array}$ & DNAzyme & Animal & Xenograft & Dose regime & Outcome & Reference \\
\hline & & $\begin{array}{l}\text { Inbred B.D.-IX } \\
\text { rats }\end{array}$ & & $\begin{array}{l}\text { Single intracranial administration of } \\
100 \mu \mathrm{g} \text { of DRz } 4 \text { with } 5 \mu \mathrm{L} \text { of saline }\end{array}$ & $\begin{array}{c}\text { Enhancement of survivability } \\
\text { of tested animals }\end{array}$ & \\
\hline \multirow[t]{3}{*}{ LMP1 } & DZ509 & $\mathrm{Balb} / \mathrm{c}$ nude mice & C666-1 & $\begin{array}{l}\text { When tumor size reached } 5-8 \mathrm{~mm} \text {, } \\
\text { intratumoral administration of } 33 \mu \mathrm{g} \text { of } \\
\text { DZ509 once per day for a week }\end{array}$ & Suppression of tumor growth & [117] \\
\hline & Dz1 & $\begin{array}{l}\text { Athymic Balb/c } \\
\text { nude mice }\end{array}$ & $\begin{array}{l}\text { CNE1- } \\
\text { LMP1 }\end{array}$ & $\begin{array}{c}\text { When the tumor volume reached } 60 \text { - } \\
100 \mathrm{~mm}^{3} \text {, intratumoral administration of } \\
20 \mu \mathrm{L} \text { of Dz1 with } 1 \mu \mathrm{L} \text { of FuGENE6 twice } \\
\text { a week }\end{array}$ & $\begin{array}{l}\text { Suppression of tumor growth } \\
\text { and radiosensitization }\end{array}$ & {$[126]$} \\
\hline & Dz1 & $\begin{array}{l}\text { Athymic Balb/c } \\
\text { nude mice }\end{array}$ & $\begin{array}{l}\text { CNE1- } \\
\text { LMP1 }\end{array}$ & $\begin{array}{c}\text { When the tumor volume reached } 60- \\
100 \mathrm{~mm}^{3} \text {, intratumoral administration of } \\
100 \mu \mathrm{g} \text { of Dzl with } 3 \mu \mathrm{L} \text { of FuGENE6 } \\
\text { once every three days }\end{array}$ & $\begin{array}{l}\text { Suppression of tumor growth } \\
\text { and radiosensitization }\end{array}$ & [132] \\
\hline
\end{tabular}

TABLE 5: Clinical trials of DNAzymes in cancer treatment.

\begin{tabular}{lccccccc}
\hline $\begin{array}{l}\text { mRNA } \\
\text { target }\end{array}$ & DNAzyme & $\begin{array}{c}\text { Patient } \\
\text { type }\end{array}$ & Phase & $\begin{array}{c}\text { Trial } \\
\text { size }\end{array}$ & $\begin{array}{c}\text { Transfection } \\
\text { reagent }\end{array}$ & Dose regime \\
\hline c-jun & Dz13 & BCC & 1 & 9 & $\begin{array}{c}\text { DOTAP/ } \\
\text { DOPE }\end{array}$ & $\begin{array}{c}\text { Three dose groups }(10,30 \text {, and } 100 \mu g \text { of Dz13) with three } \\
\text { patients per group. Single intratumoral administration of 50 } \mu \mathrm{L} \text { of } \\
\text { [6z13 over four weeks }\end{array}$ \\
$\begin{array}{l}\text { EBV- } \\
\text { LMP }\end{array}$ & DZ1 & NPC & 1 & 40 & Saline & $\begin{array}{c}\text { Administration into the tumor under the local anesthetization via } \\
\text { an epical endoscope at a dose of } 6 \mathrm{mg} \text { of DZ1 } 0.1 \mathrm{~mL} \text { of saline } \\
\text { per injection twice weekly over seven weeks }\end{array}$ \\
\hline
\end{tabular}

11 DNAzymes developed, DT18 was found to incur the most potent antiangiogenic activity in vitro. DT18 inhibited the growth of B16 melanoma tumors without affecting cell proliferation in vivo. Profound suppression of the nasopharyngeal carcinoma (NPC) tumor growth along with the VEGFR-1 expression further confirmed the antitumor efficacy of DT18. The downregulation of VEGFR-1 expression exerted a change in tumor vasculature and vessel permeability. Further, the administration of DT18 to healthy mice demonstrates the absence of any toxicity revealing its potentiality for cancer treatment, such as NPC.

Moreover, Zhang et al. [55] designed a VEGFR-2DNAzyme and screened against human breast cancer cells (MDA-MB-435) as a possible antiangiogenic agent in vivo. Administration of the DNAzyme into nude mice reduced the cell proliferation and induced apoptosis leading to overall tumor growth reduction. A pronounced decrease in blood vessel density with large areas of peripheral cell death in DNAzyme-treated tumor confirmed the antiangiogenic capability of the DNAzyme [55].

The AP-1 belonging to the family of basic leucine zipper (bZIP) transcription factors controls vital cellular processes such as differentiation, migration, proliferation, and apoptosis [56]. C-jun is a significant component of the AP-1 complex and is dysregulated in many types of cancers such as colorectal, adenocarcinoma, lung, and breast cancer tumors [57]. Moreover, elevated levels of c-jun have been shown to induce an invasive cancer phenotype in MCF-7 cells and impose drug resistance in human leukemia cells [56]. As a consequence, c- jun knockdown has become an ideal aspect of perturbing many cancers. The c-jun-Dz13 DNAzyme was capable of inhibiting c-jun protein expression and subsequent c-jun DNAbinding activity. It also attenuated the proliferation, migration, invasion, and tubule formation and blocked the expression and proteolytic activity of MMP-2 in human microvascular endothelial cell (HMEC-1) in vitro.

Moreover, it was capable of inhibiting VEGF165induced neovascularization in vivo. These antiangiogenic properties of Dz13 were employed in alleviating the growth of solid melanomas in vivo. The administration of Dz13 retarded the solid B16 melanoma growth and inhibited the tumor vascular density, indicating the involvement of Dz13-mediated c-jun knockdown in inhibiting growth and angiogenesis of solid tumors [58].

3.3. DNAzymes Targeting Apoptosis. Apoptosis is the natural mechanism of programmed cell death. It is a regulated process that eliminates any unnecessary or unwanted cells. Apoptosis is carried out by a series of cysteine protease known as caspases that cleave hundreds of various target proteins [59].

It has been reported that the loss of caspase- 2 results in an increased ability of cells to acquire a transformed phenotype and gain malignancy, suggesting that caspase- 2 is a tumor suppressor protein [60]. Dass et al. [60] presented a strong caspase-2 activation as an off-target effect of Dz13 both in vitro and in vivo. Exposure to Dz13 resulted in apoptosis in human tumor cells used in the study. Cytochrome $\mathrm{C}$ release caused by Dz13 indicated the permeabilization of 
mitochondria and confirmed apoptotic cell death. Interestingly, Dz13-mediated cell death occurred even in the absence of piddosomal components such as a p53-induced protein with a death domain (PIDD), RIP-associated Ich1/CED homologous protein with death domain (RAIDD), and DNA-dependent protein kinase catalytic subunit (DNA-PKcs), which are known to activate caspase-2 [60]. Dz13 has also exhibited anticancer activity via the caspase10-mediated apoptotic cell death in an orthotopic model of liposarcoma (LS) [61].

Furthermore, Dz13 was screened against basal cell carcinoma (BCC) and squamous cell carcinoma (SCC) in a therapeutic setting with established tumors in both immunocompromised and immunocompetent mice [62]. Intratumoral administration of Dz13 produced a prominent tumor growth suppression in immunocompetent syngeneic mice, suggesting adaptive immune system involvement in DNAzyme-mediated tumor growth suppression. Dz13 has increased the percentage of $\mathrm{CD}^{+}$and $\mathrm{CD}{ }^{+}$cells in SCC tumors of immunocompetent mice. Incorporating a $\mathrm{G}>\mathrm{C}$ point mutation to the catalytic domain of the DNAzyme (Dz13.G>C) eliminated the tumor inhibition indicating the necessity of an intact catalytic domain to drive DNAzymemediated tumor inhibition. Exposure to Dz13 inhibited the expression of mitogenic markers such as proliferating cell nuclear antigen (PCNA) and cyclin-dependent kinase 4 (CDK4) and tumorigenic markers like MMP-2, MMP-9, VEGF-A, and FGF-2 in SCC tumors. Further, Dz13 treatment enhanced the expression of the CDK inhibitor p21 $1^{\text {WAFI/Cip } 1}$ and proapoptotic markers such as caspase-3, caspase-8, caspase-9, and p53 thereby increasing the apoptosis of SCC tumors [62]. Importantly, Dz13 was found to be safe and well-tolerated, and it did not impact more than 70 different biologically relevant assays, which led to the evaluation of Dz13 in first-in-human clinical trials as a potential therapeutic against skin cancer [62].

Accordingly, Cho et al. [63] conducted a first-in-class, first-in-human (DISCOVER) phase I trial to evaluate the safety and tolerability of Dz13 in patients with BCC. The intratumoral injection of Dz13 reduced the c-jun expression in BCC of all the test participants. As per data, a single administration of Dz13 affected the expression of a range of proteins associated with tumorigenesis, for instance, increased levels of caspase-3, caspase-8, caspase-9, and p53 and decreased levels of antiapoptosis mediators Bcl-2 and MMP-9. The major changes brought about by Dz13 in the population of immune and inflammatory cells such as $\mathrm{CD}^{+}, \mathrm{CD}^{+}, \mathrm{CD}^{+}$, and $\mathrm{CD}^{+} \mathrm{a}^{+}$dendritic cells suggested the involvement of inflammatory and adaptive immune response with DNAzyme-mediated apoptosis. Further, five out of nine test participants showed a reduction in histological tumor depth. Dz13, as suggested by the study, is safe and tolerable without detectable systemic exposure following a single intratumoral injection and possibly debulks the tumor prior to excision. This indicates the emergence of promising treatment options for c-jun-associated pathologies.

Dysregulation of IGF-II is associated with the attenuation of apoptosis and increased proliferation in HCC, leading to uncontrolled tumor growth and chemoresistance
[41]. Properties of HCC that arise due to its heterogeneity such as rapid development, early metastasis, and difficulty in establishing prognosis and survival time led Zhang et al. [41] to develop two DNAzymes, namely, IGF-IIP3-DRz1 and IGF-IIP3-DRz2, and to evaluate their antitumorigenic properties in various HCC cell lines. DRz1 was shown to be more effective than DRz2 in downregulating the expression of IGF-IIP3 at both mRNA and protein levels. Furthermore, DRz1 inhibited cell proliferation and induced latestage apoptosis and necrosis in the SMMC-7721 cell population. DRz1-mediated inhibition of expression of IGF-IIP3 downregulated the expression of procaspase- 3 and procaspase- 9 and concomitantly increased caspase- 3 and caspase-9 suggesting its caspase-dependent apoptosis through the intrinsic and mitochondrial pathway [41].

Inhibitors of apoptosis proteins (IAP) are a family of proteins that regulate apoptosis and a variety of biological processes such as immune response, cellular stress, translation, transcription, cell proliferation, differentiation, motility, and signal transduction [64]. Survivin is one of the eight members of the human IAP family known as an apoptosis inhibitor and mitosis regulator [65]. It is overexpressed in tumor cells and promotes tumor cell progression by dysregulating apoptosis and cell division and promoting chemoresistance and survival of cancer stem cells [66]. Survivin is considered a potential tumor antigen as its expression is tumor-specific. The blockage of survivin by means of both immunotherapeutic and molecular approaches is emerging as a promising strategy in treating various cancers, for instance, pancreatic and breast cancer. SD is an antisurvivin DNAzyme that was transfected into the human pancreatic carcinoma cell line (PANC-1) to examine its effectiveness as a tool in pancreatic cancer gene therapy [67]. It was observed that SD was capable of effective target cleavage, increasing apoptosis, and inhibiting the growth of PANC-1. It was suspected that SD induced apoptosis of PANC-1 through the activation of caspase- 9 though it remains to be confirmed. Furthermore, SD could block the cells from entering into the $S$ phase and inhibited PANC-1 cells from passing through the G2/M checkpoint resulting in inhibition of cell proliferation [67].

DRz1 and DRz2, another two survivin-specific DNAzymes, were transfected into MCF-7 to evaluate their potential as a breast cancer gene therapy. The DNAzymes were capable of downregulating the expression of survivin at both mRNA and protein levels. DRz1 exhibited a profound effect in inhibiting cell proliferation, inducing late-stage apoptosis, and suppressing motility and migration of MCF-7 cells. The downregulation of the expression of procaspase- 3 and procaspase- 9 and concomitant increase in caspase- 3 and caspase-9 suggested the probable caspase-dependent apoptosis by DRz1 through the intrinsic and mitochondrial pathway [68].

The Bcl-2 family of proteins is well-known for their involvement in regulating apoptotic cell death [69]. Some members of the Bcl-2 family induce apoptosis (proapoptotic-Bax, Bcl-XS, Bak, Bad, Bik, Bid, Bim, Hrk, and Bok) while others suppress apoptosis (antiapoptotic-Bcl-2, BclXL, Mcl-1, A1/Bfl-1, and Bcl-W) [70]. Antiapoptotic proteins such as Bcl-2 and Bcl-XL are frequently overexpressed 
in a broad range of human cancers, including glioblastoma, colorectal carcinoma, and breast cancer [69]. The targeted knockdown or silencing of the antiapoptotic Bcl-2 family can induce apoptosis which can be implemented as a novel cancer treatment strategy. Resultantly, $\mathrm{Yu}$ et al. [69] designed Bcl-XL-DT882 DNAzyme and transfected it into various cancer cell lines to determine its capability in downregulating $\mathrm{Bcl}-\mathrm{XL}$ expression. DT882 reduced the $\mathrm{Bcl}-\mathrm{XL}$ gene expression and enhanced the release of cytochrome $\mathrm{C}$, thereby inducing apoptosis via the mitochondrial pathway in tested cells. In addition, the combined treatment of DT882 and Taxol sensitized all the cancer cells to Taxol treatment and resulted in profound apoptosis. DT882treated Taxol-resistant cells showed a reduction in cell survival, indicating the DNAzyme-mediated downregulation of Bcl-XL expression in reversing the chemoresistant phenotype of cancer cells. Furthermore, the combined application of DT882 and Taxol markedly inhibited PC3 tumor growth in vivo, representing the potency of DT882 as a chemoadjuvant in cancer therapy [69].

3.4. DNAzymes Targeting Cancer-Related Kinases. Protein kinases catalyze protein phosphorylation which is an indispensable mechanism in regulating various cellular functions, including proliferation, motility, cell cycle, apoptosis, growth, and differentiation [71]. Deregulation of kinase activity can result in dramatic changes in these processes and are frequently found to be oncogenic, contributing to cancer cell survival and spread [72].

Aurora kinases are highly conserved serine/threonine kinases consisting of three members: Aurora-A, Aurora-B, and Aurora-C [73]. Among them, Aurora-A, located on the centrosome, is required for centrosome separation [74], bipolar-spindle assembly [75], and mitotic entry [76]. Its amplification and upregulation can induce chromosomal instability, leading to aneuploidy and cell transformation in several types of cancers [77], such as the bladder, breast, gastric, prostate, and colorectal cancer [73], making Aurora-A a promising target in cancer therapy.

The Aurora-A-DZ2 DNAzyme was evaluated for its efficacy against the progression of the PC-3 cell line both in vitro and in vivo. Upon transfection, DZ2 resulted in inhibitory effects on cell proliferation, cell cycle progression, and cell migration. Moreover, DZ2 markedly increased the caspase- 3 and attenuated c-Myc and hTERT, reducing telomerase activity and ultimately enhancing apoptosis. Apart from the contribution of telomerase inhibition, induced apoptosis is also thought to be linked to other mechanisms that come to the surface through the DNAzyme-mediated Aurora-A knockdown [78]. These in vitro findings are compatible with Xing et al. [79] who used N-acetyl-L-leucinepolyethyleneimine ( $\mathrm{N}$-Ac-L-leu-PEI) as a carrier, thereby achieving an excellent delivery of the DNAzyme into PC-3 cells. Importantly, multipoint intratumoral injection of DZ2 to a human prostate cancer xenograft in nude mice produced a distinct tumor growth inhibition without noticeable adverse effects in vivo. These findings suggest the feasibility of DNAzymes targeting Aurora-A in the treatment of prostate cancer.
Philadelphia chromosome $(\mathrm{Ph})$ is the hallmark of chronic myeloid leukemia (CML) [80] along with some other leukemias, including acute lymphoblastic leukemia (ALL), acute myeloid leukemia (AML), chronic neutrophilic leukemia (CNL), and mixed phenotype acute leukemia (MPAL) [81]. It is generated when the protooncogene Abelson murine leukemia gene $(\mathrm{ABL})$ translocates to the breakpoint cluster gene (BCR), forming a BCR-ABL fusion gene [81].

According to different breakpoints in the BCR gene, three other BCR-ABL proteins are formed: p190 (e1:a2), p210 (b2:a2 and b3:a2), and p230, which are usually associated with ALL, CML, and CNL, respectively [82]. Both p190 and p210 have augmented tyrosine kinase enzymatic activity [10], resulting in continued cell proliferation, inhibited cell differentiation, and apoptosis [80]. Although tyrosine kinase inhibitors (TKI) belonging to different generations are utilized to treat CML [83], DNAzymes targeting BCR-ABL mRNA to inhibit gene expression and cell growth seem to be striking strategies when dealing with CML. S1bcrGUDz is one such DNAzyme targeting p210 ${ }^{\mathrm{BCR}-\mathrm{ABL}}$ (b3:a2) mRNA. S1bcrGUDz was capable of specifically inhibiting the target protein expression and cell growth upon transfection into $\mathrm{Ph}^{+}$cells [10]. When a $\mathrm{Ph}+$ cell line (BV173) transfected with p210 ${ }^{\text {BCR-ABL }}$ (b2:a2)-MeODz3 DNAzyme resulted in induced apoptosis without any off-target effects [84], the T315I mutant of BCR-ABL has been reported to show resistance to TKI, such as imatinib and dasatinib, used in CML patients [85]. Consequently, Kim et al. [86] designed BCR-ABL ${ }_{\mathrm{T} 315 \mathrm{I}}-\mathrm{T} 315 \mathrm{IDz}$ DNAzyme and transfected it into imatinib-resistant $\mathrm{BaF} 3 / \mathrm{BCR}-\mathrm{ABL}_{\mathrm{T} 315 \mathrm{I}}$ to identify its potential in downregulating $\mathrm{BCR}-\mathrm{ABL}$ expression and restoring drug sensitivity. Exposure to $\mathrm{T} 315 \mathrm{IDz}$ effectively reduced the expression of $\mathrm{BCR}-\mathrm{ABL}_{\mathrm{T} 315 \mathrm{I}}$, inhibited cell viability, suppressed the cell growth rate, and induced apoptosis by upregulating caspase- 3 and caspase- 7 activity. Notably, the combined treatment of imatinib and T315IDz markedly increased the frequency of apoptosis, revealing the ability of $\mathrm{T} 315 \mathrm{IDz}$ to restore the imatinib sensitivity. DNAzymemediated $\mathrm{BCR}-\mathrm{ABL}_{\mathrm{T} 315 \mathrm{I}}$ knockdown and inhibitory effect of imatinib on the PI3k/AKT signaling pathway together enhanced the effectiveness of combined treatment against leukemia cells. Despite these promising in vitro analyses, thorough in vivo studies are compulsory for the treatment of CML.

Acute promyelocytic leukemia (APL), a distinct subtype of AML [87], is characterized by a balanced translocation $\mathrm{t}(15 ; 17)$ that involves the retinoic acid receptor $\alpha(\operatorname{RAR} \alpha)$ gene on chromosome 17 and promyelocytic leukemia (PML) gene on chromosome 15, ultimately resulting in a PML/RAR $\alpha$ fusion gene [88]. PML/RAR $\alpha$ is critical in the development of APL [89]. Almost all de novo APL patients undergo disease remission under the treatment of all-transretinoic acid (ATRA), with chemotherapy eventually giving rise to clinical ATRA resistance [90]. Kabuli et al. [89] probed the feasibility of a molecular approach using DNAzymes, DZ1 and DZ3, targeting a PML/RAR $\alpha$ fusion transcript in search of promising therapeutic tools for APL. Transfection of DNAzymes into the APL cell line (NB4) 
resulted in suppressing PML/RAR $\alpha$ expression at mRNA and protein levels, inhibited cell viability, attenuated cell proliferation, and induced apoptosis. The combined treatment of DNAzymes and ATRA produced similar effects on NB4 cells but more intensely than the DNAzyme treatment alone.

Akt (protein kinase B, PKB) is activated in cells upon exposure to the diverse array of stimuli such as hormones, growth factors, and extracellular matrix components in a phosphoinositide 3-kinase- (PI3k-) dependent manner [91]. It comprises three isoforms known as Akt1, Akt2, and Akt 3 [92]. Upon activation, Akt regulates the function of many cellular proteins involved in metabolism, apoptosis, proliferation, survival, growth, and angiogenesis [93]. It has been found that the activation of Akt contributes to cancer initiation and maintenance, confers resistance to chemotherapy and radiation, and is a low prognostic factor for many cancers [91]. Aberrant activation through amplification of Akt genes or mutations in the components of the PI3K/Akt signal transduction pathway boots cell proliferation and survival, thereby contributing to cancer progression [94].

Yang et al. [95] synthesized five DNAzymes targeting Akt1 mRNA and transfected them into the NPC cell line (CNE-LMP1) to determine their effects on cell proliferation and apoptosis in NPC. Among them, Dz2 downregulated the expression of Akt1 at both mRNA and protein levels, inhibited cell proliferation, and induced apoptosis via Bcl-2 and Bax molecules in tested cells in vitro. Moreover, intratumoral administration of Dz2 to NPC xenograft growth in nude mice attenuated solid tumor development in vivo. DRz1, another anti-Akt1 DNAzyme tested against a human thyroid cancer cell line (SW597) in vitro, downregulated the Akt1 expression, inhibited cell proliferation and invasion, and induced apoptosis via the caspase-dependent manner. Further, the DNAzyme-mediated downregulation of VEGF and MMP-9 is thought to be associated with inhibited invasion and motility of SW597 cells [91].

Protein kinase C (PKC) is a family of critical signaling molecules in the VEGF pathway. It modulates the effects of extracellular stimuli such as growth factors, hormones, and drugs and promotes lipid hydrolysis [96]. Specifically, PKC $\alpha$ is upregulated in certain cancers such as bladder, endometrial, and breast cancers and is downregulated in others such as colorectal cancer and malignant renal cell carcinoma [97]. This indicates its intricate and highly tissue-specific functions, which render it a limited success as a drug target for cancer. The involvement of PKC $\alpha$ in the growth and progression of lung carcinomas and gliomas is well documented $[98,99]$. In this respect, Sioud and Leirdal [100] investigated the efficacy of PKC $\alpha$-DRz4 DNAzyme as a means of therapeutic strategy against human glioma (T98G). Exposure to DNAzyme attenuated the expression of PKC $\alpha$ at the protein level, inhibited cell proliferation, suppressed the Bcl-XL expression, and induced apoptosis of T98G cells. As per in vivo treatment, improved survivability of rats bearing intracranial tumor $\mathrm{BT}_{4} \mathrm{C}$ under single injection of $\mathrm{DRz} 4$ in combination with the continuous delivery of endostatin symbolizes an attractive therapeutic model against malignant gliomas [101].
3.5. DNAzymes Targeting Cancer-Related Specific Alleles. Protooncogenes present in normal cells function as growth factors, inducers of cellular signals, and nuclear transcription factors controlling cell differentiation and proliferation [102]. Modifications of these genes known as oncogenes are crucial in the appearance of cancer cells. Chromosomal translocation, point mutation, deletion, amplification, and insertion activation are considered genetic changes and contribute to oncogene generation via protooncogenes [103].

The Ras gene family encodes three homologous proteins, namely, $\mathrm{H}_{-}, \mathrm{N}-$, and $\mathrm{K}$-Ras, that occur exclusively at the inner plasma membrane. Ras proteins are small GTPases that function as regulators of cellular signal transduction controlling cytoskeletal integrity, cell proliferation, cell differentiation, cell adhesion, apoptosis, and cell migration [82]. Point mutations in the Ras gene, typically at codon 12,13 , or 61 , are frequently found in human cancers [104]. $K$-Ras mutations prevail in the pancreatic, endodermal, colorectal, biliary tract, cervical, and lung cancers [82], whereas $\mathrm{N}$-Ras and $\mathrm{H}$-Ras mutations are typically encountered in melanoma and bladder cancer, respectively [105]. These point mutations make the Ras proteins impervious to GTP-induced hydrolysis of GTP to GDP and remain in the activated form [105]. Activating mutations in Ras induce constitutive signaling to downstream Ras effectors such as PI3k/Akt and Raf-MEK-ERK pathways [106]. Inhibition of Ras effector pathways has paved the way for the development of novel anticancer therapeutics. Consequently, $K$ Ras(G12V)-DZ-A DNAzyme was examined using a human colon adenocarcinoma cell line (SW480) which contained homozygous $K$-Ras $(\mathrm{G} 12 \mathrm{~V})(\mathrm{GGT} \rightarrow \mathrm{GTT})$ mutant to determine its biological activity. DZ-A reduced K-Ras(G12V) expression at mRNA and protein levels in SW480 cells. Although $\mathrm{K}$-Ras $(\mathrm{G} 12 \mathrm{~V})$-specific DNAzyme was unable to inhibit the proliferation of tested cells, the treatment of DZ-A reduced $\mathrm{IC}_{50}$ of doxorubicin for SW480 cells indicating its ability to sensitize tested cells to anticancer drugs. Also, the combined effect of DZ-A and radiation synergistically reduced the viability of SW480 cells [107].

Mutations in the epidermal growth factor receptor (EGFR) are implicated in NSCLC [108]. EGFR mutations cause uncontrolled cell proliferation and metastasis, leading to cancer development [109]. EGFR genes in NSCLC patients bear mutations in exons 18-20, including deletions of amino acids from 746 to 750 in exon 19 or point mutations such as T790M in exon 20 and L858R in exon 21 [110]. The exon 19 deletion and L858R point mutation result in uncontrolled proliferation of cancer cells by enhancing the kinase activity of EGFR [108]. A DNAzyme, Ex19delDZ, was developed to specifically cleave mutant EGFR mRNA to suppress lung cancer cell viability. DNAzyme treatment effectively suppressed the mutant EGFR expression in PC9/GR cells harboring E746 A750 deletion and $\mathrm{T} 790 \mathrm{M}$ point mutation along with a concomitant attenuation of EGFR downstream signaling factor ERK1/2. Ex19delDZ reduced PC9/GR cell viability and was superior to EGFR siRNA for suppressing lung cancer cell proliferation due to the combination of nonspecific oligonucleotide and sequence-specific EGFR mRNA cleavage effects. The 
CpG sites of the Ex19delDZ upregulated the toll-like receptor 9 (TLR 9), rendering it an immunostimulatory effect, and subsequent activation of the p38 MAP kinase pathway and IL-6 secretion corresponding to induced apoptosis in EGFR-mutant lung cancer cells. The dual impact of CpGEx19delDZ, TLR9 activation, and EGFR downregulation brought about apoptosis and strong suppression of lung cancer cell proliferation, making the DNAzyme a potential agent in lung cancer therapeutics [108].

3.6. DNAzymes Targeting Oncogenic Viruses. Viral infections account for a substantial proportion of human cancers and stand as etiological agents for approximately $12 \%$ of all human cancers worldwide [111]. Six human viruses have been identified by the International Agency for Research on Cancer (IARC) as "carcinogenic to humans." These include Epstein-Barr virus (EBV), hepatitis B virus (HBV), human papillomavirus (HPV) of several types, human T cell lymphotropic virus type 1 (HTLV-1), hepatitis C virus (HCV), and Kaposi's sarcoma-associated herpesvirus (KSHV) [112]. Some viral proteins are directly involved in the dysregulation of cellular processes leading to tumor progression, and therefore, targeting these oncoproteins delivers an excellent potential for virus-associated cancer therapies.

EBV is a gammaherpesvirus that infects more than $90 \%$ of the world's population and is linked to several human malignancies, including Burkitt's and Hodgkin's lymphomas, gastric carcinoma, and NPC [113]. Latent membrane protein 1 (LMP1) is a significant oncoprotein encoded by EBV and is associated with tumor necrosis factor receptorassociated factors (TRATs), tumor necrosis factor receptorassociated death domain protein (TRADD), and receptorinteracting protein (RIP) [113]. LMP1 activates several signal transduction pathways, including NF- $\kappa \mathrm{B}$, the mitogenactivated protein kinases JNK and p38, the small GTPase Cdc42, and the JAK/STAT cascade [114], and causes various downstream pathological changes in cell proliferation, antiapoptosis, and metastasis [115]. The downregulation of LMP1 expression has provoked many scientists in search of therapeutics against EBV-associated human cancers. Consequently, Lu et al. [116] formulated 13 different DNAzymes against LMP1 mRNA and transfected them into B95-8 cells. Three DNAzymes, namely, Dz1, Dz7, and Dz10, downregulated the expression of LMP1 and inhibited B95-8 cell growth by arresting them at the G0/G1 checkpoint. Furthermore, the concomitant downregulation of the $\mathrm{Bcl}-2$ gene expression indicated a close relationship between the LMP1 and Bcl-2 at a gene-specific level and their involvement in apoptosis. The DNAzymes induced the release of cytochrome $\mathrm{C}$ from mitochondria confirming the apoptosis. These findings encouraged $\mathrm{Ke}$ et al. [117] to evaluate the therapeutic effects of LMP1-targeted DNAzymes against NPC growth in vivo. Resultantly, DZ509 DNAzyme was designed and injected directly into the C666-1 xenograft mouse model. Intratumoral administration of DZ509 downregulated the LMP1 expression, concomitantly suppressing the tumor growth. These results indicated the therapeutic implications of DNAzymes targeting LMP1 in the treatment of NPC, albeit challenging.
Cervical cancer is stated as the fourth most common cancer in women. The link between genital HPV infections and cervical cancer was first demonstrated in the early 1980s by zur Hausen [118]. HPV-16 is a high-risk HPV strain and is considered the principal causal agent in cervical cancer [119]. It encodes two oncogenes, E6 and E7, which are associated with the initiation and progression of cervical cancer [120]. E6 and E7 expression promotes cell proliferation and the chance of malignancy by inactivating two tumor suppressor proteins, namely, p53 and retinoblastoma proteins [121]. In attempts of unveiling potential treatment options for cervical cancer, Reyes-Gutiérrez and AlvarezSalas, [120] developed two DNAzymes against HPV-16 E6/E7 mRNA, out of which only one, Dz1023-434, produced an efficient cleavage against a bona fide antisense window at nt 410-445 within HPV-16 E6/E7 mRNA under the physiological range of $\left[\mathrm{Mg}^{+2}\right](1-5 \mathrm{mM})$. Optimized and chemically modified Dz1023-434 named Dz434-LNA resulted in a profound cleavage of full E6/E7 transcripts. A cervical tumor cell line (SiHA) transfected with Dz434-LNA presented a sharp reduction in E6/E7 mRNA levels, resulting in decreased proliferation and induced apoptosis, suggesting that DNAzymes are a probable cervical cancer treatment option.

3.7. DNAzymes Enhancing Cell Radiosensitivity. Radiosensitivity is the response of the tumor to irradiation which is measured by regression extent, response velocity, and response durability [122]. It depends on several factors that include the ability to repair the damage, hypoxia, cell cycle position, growth fraction, and the volume of the initial tumor [122]. Tumor cells are sensitive to ionizing radiation (IR), and therefore, radiotherapy has become an apparent cancer treatment option. Radiotherapy induces DNA damage and triggers the production of reactive oxygen species (ROS) in cancer cells [123]. Radiotherapy combined with immunotherapy and chemotherapy reduces tumor oxygen consumption and alters tumor immune response causing substantial clinical improvements in many types of cancer [123].

NPC that arises from the epithelial lining of the nasopharynx is a highly metastatic cancer with unique clinical and pathological characteristics. NPC is highly radiosensitive, and therefore, radiotherapy or radiotherapy in combination with chemotherapy is the main treatment strategies [124]. However, along with radiotherapy, radioresistance exists in many cases causing locoregional recurrence and distant metastasis after radiotherapy, especially in patients with tumors in advanced stages (stage III or IV) [125]. As a consequence, the DNAzyme-mediated downregulation of LMP1 expression is found to be effective in enhancing the radiosensitivity of EBV-related malignancies.

In their study, Lu et al. [126] used three DNAzymes, Dz1, Dz7, and Dz10, targeting LMP1 mRNA and transfected them into CNE1-LMP1 cells. The DNAzymes inhibited the LMP1 protein expression in tested cells leading to an inhibition of cellular signal transduction pathways which are abnormally activated by LMP1 such as AP1, NF- $\kappa \beta$, and JAK/STAT, suppressed cell proliferation by arresting cells 
at the $S$ phase, and induced apoptosis via the mitochondrial pathway by increasing the activity of caspase-3, caspase-8, and caspase- 9 concomitantly downregulating the expression of the antiapoptotic Bcl-2 gene. Moreover, the combined treatment of DNAzymes and IR increased the apoptotic rate and inhibited cell proliferation and colony-forming ability indicating DNAzyme-mediated downregulation of LMP1 expression in sensitizing CNE1-LMP1 cells to irradiation. Further, the effects of Dzl on tumor growth were tested using CNE1-LMP1 carcinomas grown in nude mice in vivo. Subcutaneous injection of Dz1 combined with radiation treatment resulted in marked suppression of LMP1 expression, which led to a prominent tumor size reduction and enhanced the radiosensitivity of NPC cells.

Hypoxia-inducible factor-1 (HIF-1) is a heterodimeric transcriptional factor composed of HIF- $\alpha$ and HIF- $\beta$ [127] and plays key roles in regulating tumor radiosensitivity [128]. HIF-1 is activated by hypoxia that modulates many genes involved in regulating critical processes such as metabolism, proliferation, apoptosis, and angiogenesis [129]. VEGF is one such activated gene performing vital roles in regulating tumor angiogenesis and progression [130]. It also protects endothelial cells from the cytotoxic effects of irradiation, leading to tumor radioresistance [131]. Overexpression of HIF-1 at the protein level in tumor cells corresponding to inadequate radiotherapy response has been identified in many types of cancers [129]. HIF-1 is a powerful radioreceptor, and thus, its blockade is essential in enhancing tumor radiosensitivity.

Yang et al. [132] exploited the EBV-LMP1-Dz1 DNAzyme to elucidate its potential to enhance radiosensitivity of NPC by suppressing HIF-1/VEGF activity. Dz1mediated LMP1 knockdown presented an antiangiogenic activity in tested cells by reducing the VEGF expression and its secretion and inhibiting the three-dimensional tubule formation. Moreover, upon treatment with Dz1, the levels of phosphorylated JNKs, total c-jun, and phosphorylated c-jun were reduced, and the expression of HIF-1 and VEGF was also downregulated. Dz1 treatment sensitized CNE1-LMP1 cells to radiation treatment with a marked reduction in cell viability. Notably, the combined therapy of Dz1 and IR brought about a more substantial effect on cell viability than treatments of DNAzyme or IR alone. As per in vivo analysis, the combined treatment of Dz1 and IR produced a prominent tumor growth suppression and enhanced the radiosensitivity of CNE-LMP1 xenograft in athymic nude mice.

After a successful preclinical study, Cao et al. [124] further investigated the safety and tolerability of Dz1 in treating EBVassociated NPC in a randomized and double-blind clinical setting with 40 patients either receiving Dz1 or saline intratumorally in conjunction with radiotherapy. Dz1 treatment resulted in a high tumor regression rate and impacted the microvascular tumor permeability. Importantly, Dzl treatment neither resulted in any cardiovascular, renal, and hepatic event nor increased radiation-induced toxicity. This put forward the potency of the DNAzyme-based therapeutic approach in enhancing the efficacy of radiotherapy for cancer treatment.

3.8. DNAzymes Targeting DNA Methyltransferase. Epigenetics is the study of heritable changes in gene expression that are not attributed to alterations in the primary DNA sequence. Epigenetic regulation of gene expression is governed by several mechanisms such as methylation of DNA, modifications of histones, and positioning of nucleosomes along with the DNA [133]. Among these, DNA methylation poses a great impact on cell physiology thus making it one of the widely discussed entities of epigenetic modifications in mammals. Alterations in DNA methylation interfere with transcriptional regulation leading to various diseases including cancer [134]. DNA methylation consists of covalent addition of a methyl group from S-adenosyl-L-methionine to 5-position of the cytosine moiety [135]. The reaction is catalyzed by a group of enzymes termed DNA methyltransferases (DNMTs). Such 5-methylcytosines are usually observed within $\mathrm{CpG}$ dinucleotides. DNMTs are extremely important epigenetic regulatory enzymes that take part in several biological activities such as preserving chromosome stability and genome integrity, embryo development, cell differentiation, and growth of organisms [136].

Five members of the DNMT family have been identified in mammals, and these include DNMT1, DNMT2, DNMT3a, DNMT3b, and DNMT3L. Nevertheless, only three, DNMT1, DNMT3a, and DNMT3b, participate in the production of cytosine methylation [136]. DNMT1 contributes to maintaining the methylation status after DNA synthesis. Its aberrations in terms of mutations, high expression, and low expression are frequently observed in various types of cancers [136] such as colorectal [137], pancreatic [138], and gastric cancer [139]. Owing to its active involvement in the development and progression of tumors, DNMT1 has become an excellent target in cancer therapy. For instance, reactivation of tumor suppressor genes (TSGs) has been silenced mainly due to the overexpression of DNMT1 using DNMT inhibitors (DNMTis) [135]. Decitabine (5-aza-2' -deoxycytidine) and azacitidine (5-azacytidine) are such DNMTis that have been tested in both preclinical and clinical settings [135]. Although effective, certain drawbacks such as substantial toxicity, poor bioavailability, and instability in physiological media trigger the development of novel and high-specific DNMT inhibitors [140].

On that account, Wang et al. [135] constructed a DNMT1-DT433 DNAzyme and validated it against T24 cells for its target-specific effect on DNA methylation and cell proliferation in vitro. Nuclear extracts from DT433transfected T24 cells resulted in 50\% reduction in methylation activity. This indicates the effective transection of DT433 into cells and its subsequent nucleic entry causing DNAzyme-dependent reduction in DNMT1 enzymatic activity. DT433 treatment inhibited the DNMT1 expression concomitantly elevating the p16 mRNA level in T24 cells thereby reactivating the tumor suppressor p16 gene. Reactivation of the p16 gene is evident from the subsequent inhibition of cell proliferation in cells treated with DT433. Interestingly, the effects incurred by DT433 on DNMT enzymatic activity, DNMT1 expression, and reactivation of the p16 gene were comparable to those of 5-Aza. This emphasizes that DT433 is as effective as such commercially available DNMTis. This preliminary study lays an alternative foundation to target DNMT for cancer treatment. This strategy was assisted with further preclinical data, and a targeted 
TABLE 6: Types of DNAzyme delivery systems and the outcomes.

\begin{tabular}{|c|c|c|}
\hline Delivery systems & Outcomes & References \\
\hline $\begin{array}{l}\text { Biodegradable poly(D, L-lactide-co-glycoid) } \\
\text { copolymer (PLGA) microspheres }\end{array}$ & Efficient and sustained delivery & {$[146]$} \\
\hline Cyclodextrin-containing polycation (CDP) & A rapid and efficient intracellular uptake into various cell lines & [147] \\
\hline Branched polyethylenimine & $\begin{array}{l}\text { Higher biocompatibility and efficient transfection. Less cytotoxicity and } \\
\text { promote gene dissociation }\end{array}$ & [148] \\
\hline $\begin{array}{l}\mathrm{N} \text {-Acetyl-L-leucine-polyethylenimine }(\mathrm{N}- \\
\text { Ac-L-Leu-PEI) }\end{array}$ & Efficient cellular uptake and exhibited protective function against nucleases & {$[79]$} \\
\hline Dendrimers & Low toxicity, higher water solubility, and increased stability against hydrolysis & [149] \\
\hline $\begin{array}{l}\text { Modified fourth-generation dendrimers } \\
\text { termed G4 (MeI) }\end{array}$ & Efficient DNAzyme delivery without substantial toxicity & [149] \\
\hline Colloidal gold nanoparticles & Less toxic and an efficient DNAzyme transfection & {$[150]$} \\
\hline Liposomes & Efficient targeted delivery & {$[151-153]$} \\
\hline \multirow{2}{*}{ Chitosan nanoparticles } & $\begin{array}{l}\text { Effective cellular uptake ability, remain stable at room temperature for a month } \\
\text { and for seven days in serum without a substantial loss in activity }\end{array}$ & {$[154-156]$} \\
\hline & $\begin{array}{c}\text { Toxic side effects such as myelosuppression, alopecia, and hepatic toxicity can } \\
\text { be associated }\end{array}$ & {$[157]$} \\
\hline
\end{tabular}

drug delivery system would be effective in the development of potential cancer treatment options.

\section{A Glance into DNAzyme Delivery Systems}

DNAzymes indeed are beneficial compared to other common nucleic acid-based therapeutic strategies yet influenced by factors such as serum stability and efficient delivery when it comes to in vivo applications. DNAzymes need to travel from the administration site, through the circulation and the tumor stroma, ultimately to their target cancer cells. Nucleic acids are potentially immunogenic and typically require a delivery tool to be utilized as therapeutics. An ideal delivery system is characterized by high transfection efficiency with a high degree of target cell specificity, low occurrence of toxicity and immunogenicity, biodegradability, stability, simple formulation, and versatility [141]. Tremendous efforts have been made to develop DNAzyme delivery systems that encircle all these characteristics to the best possible extent. Table 6 summarizes the different types of delivery systems evaluated for efficient delivery of DNAzymes into cells and tissues, and the main outcomes of the respective studies are presented herein.

\section{Conclusion}

DNAzymes have been extensively assessed as effective anticancer agents following their discovery a decade and a half ago. Accompanied by the pioneering works of Breaker and Joyce in 1994, several structural modifications have been introduced to DNAzymes to enhance the stability and potency as an anticancer therapeutic agent. Many preclinical studies using in vitro assays and animal tumor models have revealed that DNAzymes may have clinical utility as an anticancer agent. These come with inherent pros and cons that incite further investigations in making DNAzymes a reality in the clinical arena. The therapeutic potential of DNAzymes lies in the design of special delivery systems that circumvent natural barriers to DNAzyme transport. Attempts at drug delivery systems (DDSs) such as conjugations of DNAzymes to cationic liposomes, cationic polypeptides, and nanotechnology have been employed to achieve efficient intracellular delivery of DNAzymes. DNAzymes have started to step forward from preclinical to clinical scenarios in light of these advances. Thus far, few clinical trials have validated the safety and tolerability of DNAzymes as therapeutic adjuvants. Although the development of DNAzymes as drugs is in its early stages of evolution, the emergence of economic and feasible DNAzyme-based cancer therapy is not far.

\section{Conflicts of Interest}

The authors declare that there are no conflicts of interest regarding the publication of this paper.

\section{Acknowledgments}

Accelerating Higher Education Expansion and Development (AHEAD) Operation, Sri Lanka, funded by the World Bank (AHEAD Grant No. DOR_28), is acknowledged for the financial support.

\section{References}

[1] J. N. Bailey, M. A. Pericak-Vance, and J. L. Haines, "The impact of the human genome project on complex disease," Genes, vol. 5, no. 3, pp. 518-535, 2014.

[2] O. W. Kotagama, C. D. Jayasinghe, and T. Abeysinghe, "Era of genomic medicine: a narrative review on CRISPR technology as a potential therapeutic tool for human diseases," BioMed research international, vol. 2019, 2019.

[3] K. Sridharan and N. J. Gogtay, "Therapeutic nucleic acids: current clinical status," British journal of clinical pharmacology, vol. 82, no. 3, pp. 659-672, 2016. 
[4] S. W. Santoro and G. F. Joyce, "A general-purpose RNAcleaving DNA enzyme," Proceedings of the National Academy of Sciences of the United States of America, vol. 94, no. 9, pp. 4262-4266, 1997.

[5] P. Saraswat, R. R. Soni, A. Bhandari, and B. P. Nagori, "DNA as therapeutics; an update," Indian J Pharm Sci., vol. 71, no. 5, pp. 488-498, 2009.

[6] J. Zhang, "RNA-cleaving DNAzymes: old catalysts with new tricks for intracellular and in vivo applications," Catalysts, vol. 8, p. 550, 2018.

[7] R. R. Breaker and G. F. Joyce, "A DNA enzyme that cleaves RNA,” Chemistry \& biology, vol. 1, no. 4, pp. 223-229, 1994.

[8] R. B. Remant, B. Thapa, J. Valencia-Serna, H. M. Aliabadi, and H. Uludağ, "Nucleic acid combinations: a new frontier for cancer treatment," Journal of Controlled Release, vol. 256, pp. 153-169, 2017.

[9] C. R. Dass, P. F. Choong, and L. M. Khachigian, "DNAzyme technology and cancer therapy: cleave and let die," Molecular cancer therapeutics, vol. 7, no. 2, pp. 243-251, 2008.

[10] Y. Wu, L. Yu, R. McMahon, J. J. Rossi, S. J. Forman, and D. S. Snyder, "Inhibition of bcr-abl oncogene expression by novel deoxyribozymes (DNAzymes)," Human gene therapy, vol. 10, no. 17, pp. 2847-2857, 1999.

[11] W. Huo, X. Li, B. Wang et al., "Recent advances of DNAzyme-based nanotherapeutic platform in cancer gene therapy," Biophysics Reports, vol. 6, no. 6, pp. 256-265, 2020.

[12] S. Fu and L. Q. Sun, "DNAzyme-based therapeutics for cancer treatment," Future medicinal chemistry, vol. 7, no. 13, pp. 1701-1707, 2015.

[13] S. W. Santoro and G. F. Joyce, "Mechanism and utility of an RNA-cleaving DNA enzyme," Biochemistry, vol. 37, no. 38, pp. 13330-13342, 1998.

[14] Z. J. Xu, L. F. Yang, L. Q. Sun, and Y. Cao, "Use of DNAzymes for cancer research and therapy," Chinese Science Bulletin, vol. 57, no. 26, pp. 3404-3408, 2012.

[15] J. Wirmer-Bartoschek and H. Schwalbe, "Understanding how DNA enzymes work," Angewandte Chemie (International ed. in English), vol. 55, no. 18, pp. 5376-5377, 2016.

[16] S. Ni, H. Yao, L. Wang et al., "Chemical modifications of nucleic acid aptamers for therapeutic purposes," International journal of molecular sciences, vol. 18, no. 8, p. 1683, 2017.

[17] P. J. Huang and J. Liu, "In vitro selection of chemically modified DNAzymes," ChemistryOpen, vol. 9, no. 10, pp. 10461059, 2020.

[18] C. Wahlestedt, P. Salmi, L. Good et al., "Potent and nontoxic antisense oligonucleotides containing locked nucleic acids," Proceedings of the National Academy of Sciences of the United States of America, vol. 97, no. 10, pp. 5633-5638, 2000.

[19] G. A. Curt, "Cancer drug development: new targets for cancer treatment," Oncologist, vol. 1, no. 3, pp. II-III, 1996.

[20] G. M. Cooper, "The Cell: A Molecular Approach," in The development and causes of cancer, Sunderland (MA): Sinauer Associates, 2nd edition edition, 2000, https://www.ncbi.nlm .nih.gov/books/NBK9963/.

[21] H. K. Karnati, R. S. Yalagala, R. Undi, S. R. Pasupuleti, and R. K. Gutti, "Therapeutic potential of siRNA and DNAzymes in cancer," Tumour biology : the journal of the International Society for Oncodevelopmental Biology and Medicine, vol. 35, no. 10, pp. 9505-9521, 2014.
[22] S. Sarkar, G. Horn, K. Moulton et al., "Cancer development, progression, and therapy: an epigenetic overview," International journal of molecular sciences, vol. 14, no. 10, pp. 21087-21113, 2013.

[23] D. Hanahan and R. A. Weinberg, "The hallmarks of cancer," Cell, vol. 100, no. 1, pp. 57-70, 2000.

[24] T. N. Seyfried and L. C. Huysentruyt, "On the origin of cancer metastasis," Critical Reviews in Oncogenesis, vol. 18, no. 1-2, pp. 43-73, 2013.

[25] M. J. Duffy, P. M. McGowan, and W. M. Gallagher, "Cancer invasion and metastasis: changing views," The Journal of pathology, vol. 214, no. 3, pp. 283-293, 2008.

[26] B. Alberts, A. Johnson, J. Lewis, M. Raff, K. Roberts, and P. Walter, Molecular Biology of the Cell, New York: Garland Science, Integrins, 4th edition edition, 2002, https://www .ncbi.nlm.nih.gov/books/NBK26867/.

[27] R. Rathinam and S. K. Alahari, "Important role of integrins in the cancer biology," Cancer metastasis reviews, vol. 29, no. 1, pp. 223-237, 2010.

[28] M. Wiktorska, I. Papiewska-Pająk, A. Okruszek, I. SacewiczHofman, and J. Niewiarowska, "DNAzyme as an efficient tool to modulate invasiveness of human carcinoma cells," Acta biochimica Polonica, vol. 57, no. 3, pp. 269-275, 2010.

[29] J. Niewiarowska, I. Sacewicz, M. Wiktorska et al., "DNAzymes to mouse $\beta 1$ integrin mRNA in vivo: targeting the tumor vasculature and retarding cancer growth," Cancer Gene Therapy, vol. 16, no. 9, pp. 713-722, 2009.

[30] M. Wiktorska, I. Sacewicz-Hofman, O. Stasikowska-Kanicka, M. Danilewicz, and J. Niewiarowska, "Distinct inhibitory efficiency of siRNAs and DNAzymes to $\beta 1$ integrin subunit in blocking tumor growth," Acta biochimica Polonica, vol. 60, no. 1, pp. 77-82, 2013.

[31] M. J. Duffy, "The urokinase plasminogen activator system: role in malignancy," Current pharmaceutical design., vol. 10, no. 1, pp. 39-49, 2004.

[32] H. Noh, S. Hong, and S. Huang, "Role of urokinase receptor in tumor progression and development," Theranostics, vol. 3, no. 7, pp. 487-495, 2013.

[33] V. Ellis, C. Pyke, J. Eriksen, H. Solberg, and K. Danø, “The urokinase receptor: involvement in cell surface proteolysis and cancer invasion," Annals of the New York Academy of Sciences, vol. 667, pp. 13-31, 1992.

[34] C. E. de Bock, Z. Lin, T. Itoh, D. Morris, G. Murrell, and Y. Wang, "Inhibition of urokinase receptor gene expression and cell invasion by anti-uPAR DNAzymes in osteosarcoma cells," The FEBS journal, vol. 272, no. 14, pp. 3572-3582, 2005.

[35] H. Laronha and J. Caldeira, "Structure and function of human matrix metalloproteinases," Cells, vol. 9, no. 5, p. 1076, 2020.

[36] S. Quintero-Fabián, R. Arreola, E. Becerril-Villanueva et al., "Role of matrix metalloproteinases in angiogenesis and cancer," Frontiers in oncology, vol. 9, p. 1370, 2019.

[37] L. Yang, W. Zeng, D. Li, and R. Zhou, "Inhibition of cell proliferation, migration and invasion by DNAzyme targeting MMP-9 in A549 cells," Oncology reports, vol. 22, no. 1, pp. 121-126, 2009.

[38] M. A. Hallett, B. Teng, H. Hasegawa, L. P. Schwab, T. N. Seagroves, and T. Pourmotabbed, "Anti-matrix metalloproteinase9 DNAzyme decreases tumor growth in the MMTV-PyMT mouse model of breast cancer," Breast cancer research: BCR, vol. 15, no. 1, p. R12, 2013. 
[39] K. Almholt, A. Juncker-Jensen, O. D. Lærum et al., "Metastasis is strongly reduced by the matrix metalloproteinase inhibitor galardin in the MMTV-PymT transgenic breast cancer model," Molecular Cancer Therapeutics, vol. 7, no. 9, pp. 2758-2767, 2008.

[40] M. Pollak, "Insulin and insulin-like growth factor signalling in neoplasia," Nature reviews. Cancer, vol. 8, no. 12, pp. 915-928, 2008.

[41] M. Zhang, G. P. Drummen, and S. Luo, “Anti-insulin-like growth factor-IIP3 DNAzymes inhibit cell proliferation and induce caspase-dependent apoptosis in human hepatocarcinoma cell lines," Drug design, development and therapy, vol. 7, pp. 1089-1102, 2013.

[42] J. E. Brissenden, A. Ullrich, and U. Francke, "Human chromosomal mapping of genes for insulin-like growth factors I and II and epidermal growth factor," Nature, vol. 310, no. 5980, pp. 781-784, 1984.

[43] K. Breuhahn, T. Longerich, and P. Schirmacher, "Dysregulation of growth factor signaling in human hepatocellular carcinoma," Oncogene, vol. 25, no. 27, pp. 3787-3800, 2006.

[44] S. K. Akram, M. Akram, Z. A. Bhutta, and O. Soder, "Human placental IGF-I and IGF-II expression: correlating maternal and infant anthropometric variables and micronutrients at birth in the Pakistani population," Acta paediatrica (Oslo, Norway: 1992), vol. 97, no. 10, pp. 1443-1448, 2008.

[45] M. Zhang, H. Zhao, F. Luo, S. Luo, and W. Shi, "IGF-II inhibitory DNAzymes inhibit the invasion and migration of hepatocarcinoma cells," Biotechnology letters, vol. 33, no. 5, pp. 911-917, 2011.

[46] R. G. Fahmy, C. R. Dass, L. Q. Sun, C. N. Chesterman, and L. M. Khachigian, "Transcription factor Egr-1 supports FGF-dependent angiogenesis during neovascularization and tumor growth," Nature medicine, vol. 9, no. 8, pp. 10261032, 2003.

[47] N. Nishida, H. Yano, T. Nishida, T. Kamura, and M. Kojiro, "Angiogenesis in cancer," Vascular health and risk management, vol. 2, no. 3, pp. 213-219, 2006.

[48] A. Gashler and V. P. Sukhatme, "Early growth response protein 1 (Egr-1): prototype of a zinc-finger family of transcription factors," Progress in nucleic acid research and molecular biology, vol. 50, pp. 191-224, 1995.

[49] Y. L. Hu, Z. M. Lei, Z. H. Huang, and C. V. Rao, "Determinants of transcription of the chorionic gonadotropin/luteinizing hormone receptor gene in human breast cells," The breast journal, vol. 5, no. 3, pp. 186-193, 1999.

[50] A. Mitchell, C. R. Dass, L. Q. Sun, and L. M. Khachigian, "Inhibition of human breast carcinoma proliferation, migration, chemoinvasion and solid tumour growth by DNAzymes targeting the zinc finger transcription factor EGR-1," Nucleic acids research, vol. 32, no. 10, pp. 3065-3069, 2004.

[51] A. M. Duffy, D. J. Bouchier-Hayes, and J. H. Harmey, "Vascular endothelial growth factor (VEGF) and its role in nonendothelial cells: autocrine signalling by VEGF," in In: Madame Curie Bioscience Database, Landes Bioscience, Austin (TX), 2000-2013, https://www.ncbi.nlm.nih.gov/books/NBK6482/.

[52] M. Shibuya, "Vascular endothelial growth factor and its receptor system: physiological functions in angiogenesis and pathological roles in various diseases," Journal of biochemistry, vol. 153, no. 1, pp. 13-19, 2013.

[53] L. Shen, Q. Zhou, Y. Wang et al., "Antiangiogenic and antitumoral effects mediated by a vascular endothelial growth factor receptor 1 (VEGFR-1)-targeted DNAzyme," Molecular medicine (Cambridge, Mass), vol. 19, no. 1, pp. 377-386, 2013.

[54] M. Kowanetz and N. Ferrara, "Vascular endothelial growth factor signaling pathways: therapeutic perspective," Clinical cancer research: an official journal of the American Association for Cancer Research, vol. 12, no. 17, pp. 5018-5022, 2006.

[55] L. Zhang, W. J. Gasper, S. A. Stass, O. B. Ioffe, M. A. Davis, and A. J. Mixson, "Angiogenic inhibition mediated by a DNAzyme that targets vascular endothelial growth factor receptor 2," Cancer research, vol. 62, no. 19, pp. 5463-5469, 2002.

[56] A. Brennan, J. T. Leech, N. M. Kad, and J. M. Mason, "Selective antagonism of cJun for cancer therapy," Journal of Experimental \& Clinical Cancer Research, vol. 39, p. 184, 2020.

[57] L. Blau, R. Knirsh, I. Ben-Dror et al., “Aberrant expression of c-Jun in glioblastoma by internal ribosome entry site (IRES)mediated translational activation," Proceedings of the National Academy of Sciences of the United States of America, vol. 109, no. 42, pp. E2875-E2884, 2012.

[58] G. Zhang, C. R. Dass, E. Sumithran, N. Di Girolamo, L. Q. Sun, and L. M. Khachigian, "Effect of deoxyribozymes targeting c-Jun on solid tumor growth and angiogenesis in rodents," Journal of the National Cancer Institute, vol. 96, no. 9, pp. 683-696, 2004.

[59] S. Zaman, R. Wang, and V. Gandhi, "Targeting the apoptosis pathway in hematologic malignancies," Leukemia \& lymphoma, vol. 55, no. 9, pp. 1980-1992, 2014.

[60] C. R. Dass, S. J. Galloway, and P. F. Choong, "Dz13, a c-jun DNAzyme, is a potent inducer of caspase-2 activation," Oligonucleotides, vol. 20, no. 3, pp. 137-146, 2010.

[61] C. R. Dass, S. J. Galloway, J. C. Clark, L. M. Khachigian, and P. F. Choong, "Involvement of c-jun in human liposarcoma growth: supporting data from clinical immunohistochemistry and DNAzyme efficacy," Cancer biology \& therapy, vol. 7, no. 8, pp. 1297-1301, 2008.

[62] H. Cai, F. S. Santiago, L. Prado-Lourenco et al., "DNAzyme targeting c-jun suppresses skin cancer growth," Science translational medicine, vol. 4, no. 139, p. 139ra82, 2012.

[63] E. A. Cho, F. J. Moloney, H. Cai et al., "Safety and tolerability of an intratumorally injected DNAzyme, Dz13, in patients with nodular basal-cell carcinoma: a phase 1 first-in-human trial (DISCOVER)," Lancet (London, England), vol. 381, no. 9880, pp. 1835-1843, 2013.

[64] L. Dubrez-Daloz, A. Dupoux, and J. Cartier, "IAPs: more than just inhibitors of apoptosis proteins," Cell cycle (Georgetown, Tex), vol. 7, no. 8, pp. 1036-1046, 2008.

[65] D. C. Altieri, "Survivin and apoptosis control," Advances in cancer research, vol. 88, pp. 31-52, 2003.

[66] H. Garg, P. Suri, J. C. Gupta, G. P. Talwar, and S. Dubey, "Survivin: a unique target for tumor therapy," Cancer cell international, vol. 16, p. 49, 2016.

[67] Z. Liang, S. Wei, J. Guan et al., "DNAzyme-mediated cleavage of survivin mRNA and inhibition of the growth of PANC-1 cells," Journal of gastroenterology and hepatology, vol. 20, no. 10, pp. 1595-1602, 2005.

[68] M. Zhang, Y. F. Sun, and S. Luo, “Ani-survivin DNAzymes inhibit cell proliferation and migration in breast cancer cell line MCF-7," Asian Pacific journal of cancer prevention: APJCP, vol. 13, no. 12, pp. 6233-6237, 2012.

[69] X. Yu, L. Yang, M. J. Cairns et al., "Chemosensitization of solid tumors by inhibition of Bcl-xL expression using DNAzyme," Oncotarget, vol. 5, no. 19, pp. 9039-9048, 2014. 
[70] J. C. Reed, "Mechanisms of apoptosis," The American journal of pathology, vol. 157, no. 5, pp. 1415-1430, 2000.

[71] J. Cicenas, E. Zalyte, A. Bairoch, and P. Gaudet, Kinases and Cancer. Cancers, vol. 10, no. 3, p. 63, 2018.

[72] T. Hunter and J. A. Cooper, "Protein-tyrosine kinases," Annual review of biochemistry, vol. 54, pp. 897-930, 1985.

[73] R. D. Carvajal, A. Tse, and G. K. Schwartz, "Aurora kinases: new targets for cancer therapy," Clinical cancer research : an official journal of the American Association for Cancer Research, vol. 12, no. 23, pp. 6869-6875, 2006.

[74] T. Marumoto, S. Honda, T. Hara et al., "Aurora-A kinase maintains the fidelity of early and late mitotic events in HeLa cells," The Journal of biological chemistry, vol. 278, no. 51, pp. 51786-51795, 2003.

[75] P. A. Eyers, E. Erikson, L. G. Chen, and J. L. Maller, "A novel mechanism for activation of the protein kinase Aurora A," Current biology : CB, vol. 13, no. 8, pp. 691-697, 2003.

[76] T. Hirota, N. Kunitoku, T. Sasayama et al., "Aurora-A and an interacting activator, the LIM protein Ajuba, are required for mitotic commitment in human cells," Cell, vol. 114, no. 5, pp. 585-598, 2003.

[77] M. Sun, G. Wang, J. E. Paciga et al., “AKT1/PKBalpha kinase is frequently elevated in human cancers and its constitutive activation is required for oncogenic transformation in NIH3T3 cells," The American journal of pathology, vol. 159, no. 2, pp. 431-437, 2001.

[78] Y. Qu, L. Zhang, M. Mao et al., "Effects of DNAzymes targeting Aurora kinase A on the growth of human prostate cancer," Cancer gene therapy, vol. 15, no. 8, pp. 517-525, 2008.

[79] Z. Xing, S. Gao, Y. Duan et al., "Delivery of DNAzyme targeting aurora kinase A to inhibit the proliferation and migration of human prostate cancer," International journal of nanomedicine, vol. 10, pp. 5715-5727, 2015.

[80] M. Z. Haider and F. Anwer, Genetics, Philadelphia Chromosome, StatPearls, 2021, https://www.ncbi.nlm.nih.gov/books/ NBK560689/.

[81] Z. J. Kang, Y. F. Liu, L. Z. Xu et al., "The Philadelphia chromosome in leukemogenesis," Chinese journal of cancer, vol. 35, p. 48, 2016.

[82] C. W. Han, M. S. Jeong, and S. B. Jang, "Structure, signaling and the drug discovery of the Ras oncogene protein," $B M B$ reports, vol. 50, no. 7, pp. 355-360, 2017.

[83] R. E. Eden and J. M. Coviello, Chronic myelogenous leukemia, StatPearls Publishing, 2021, https://www.ncbi.nlm.nih.gov/ books/NBK531459/.

[84] M. Warashina, T. Kuwabara, Y. Nakamatsu, and K. Taira, "Extremely high and specific activity of DNA enzymes in cells with a Philadelphia chromosome," Chemistry \& Biology, vol. 6, no. 4, pp. 237-250, 1999.

[85] M. Steinberg, "Dasatinib: a tyrosine kinase inhibitor for the treatment of chronic myelogenous leukemia and philadelphia chromosome-positive acute lymphoblastic leukemia," Clinical therapeutics, vol. 29, no. 11, pp. 2289-2308, 2007.

[86] J. E. Kim, S. Yoon, B. R. Choi et al., "Cleavage of BCR-ABL transcripts at the T315I point mutation by DNAzyme promotes apoptotic cell death in imatinib-resistant BCR-ABL leukemic cells," Leukemia, vol. 27, no. 8, pp. 1650-1658, 2013.

[87] A. Liquori, M. Ibañez, C. Sargas, M. Á. Sanz, E. Barragán, and J. Cervera, "Acute promyelocytic leukemia: a constellation of molecular events around a single PML-RARA fusion gene," Cancers, vol. 12, no. 3, p. 624, 2020.

[88] H. de Thé, C. Chomienne, M. Lanotte, L. Degos, and A. Dejean, "The $t(15 ; 17)$ translocation of acute promyelocytic leukaemia fuses the retinoic acid receptor alpha gene to a novel transcribed locus," Nature, vol. 347, no. 6293, pp. 558-561, 1990.

[89] M. Kabuli, J. A. Yin, and K. Tobal, “Targeting PML/RARalpha transcript with DNAzymes results in reduction of proliferation and induction of apoptosis in APL cells," The hematology journal : the official journal of the European Haematology Association, vol. 5, no. 5, pp. 426-433, 2004.

[90] D. C. Zhou, S. H. Kim, W. Ding, C. Schultz, R. P. Warrell, and R. E. Gallagher, "Frequent mutations in the ligand-binding domain of PML-RAR $\alpha$ after multiple relapses of acute promyelocytic leukemia: analysis for functional relationship to response to all-trans retinoic acid and histone deacetylase inhibitors in vitro and in vivo," Blood, vol. 99, no. 4, pp. 1356-1363, 2002.

[91] L. Yang, J. T. He, H. Guan, and Y. D. Sun, “AKT1 inhibitory DNAzymes inhibit cell proliferation and migration of thyroid cancer cells," Asian Pacific journal of cancer prevention: APJCP, vol. 14, no. 4, pp. 2571-2575, 2013.

[92] M. Tang, M. Iijima, Y. Kamimura, L. Chen, Y. Long, and P. Devreotes, "Disruption of PKB signaling restores polarity to cells lacking tumor suppressor PTEN," Molecular biology of the cell, vol. 22, no. 4, pp. 437-447, 2011.

[93] A. Kumar, V. Rajendran, R. Sethumadhavan, and R. Purohit, "AKT kinase pathway: a leading target in cancer research," TheScientificWorldJournal, vol. 2013, p. 756134, 2013.

[94] J. Yang, J. Nie, X. Ma, Y. Wei, Y. Peng, and X. Wei, “Targeting PI3K in cancer: mechanisms and advances in clinical trials," Molecular cancer, vol. 18, no. 1, p. 26, 2019.

[95] L. Yang, L. Xiao, X. Ma et al., "Effect of DNAzymes targeting Akt1 on cell proliferation and apoptosis in nasopharyngeal carcinoma," Cancer biology \& therapy, vol. 8, no. 4, pp. 366-371, 2009.

[96] I. Shchemelinin, L. Sefc, and E. Necas, "Protein kinases, their function and implication in cancer and other diseases," Folia biologica, vol. 52, no. 3, pp. 81-100, 2006.

[97] R. Garg, L. G. Benedetti, M. B. Abera, H. Wang, M. Abba, and M. G. Kazanietz, "Protein kinase $\mathrm{C}$ and cancer: what we know and what we do not," Oncogene, vol. 33 , no. 45, pp. 52255237, 2014.

[98] M. Sioud and D. R. Sørensen, "A nuclease-resistant protein kinase C alpha ribozyme blocks glioma cell growth," Nature biotechnology, vol. 16, no. 6, pp. 556-561, 1998.

[99] M. Leirdal and M. Sioud, "Ribozyme inhibition of the protein kinase C alpha triggers apoptosis in glioma cells," British journal of cancer, vol. 80, no. 10, pp. 1558-1564, 1999.

[100] M. Sioud and M. Leirdal, "Design of nuclease resistant protein kinase calpha DNA enzymes with potential therapeutic application," Journal of molecular biology, vol. 296, no. 3, pp. 937-947, 2000.

[101] D. R. Sorensen, M. Leirdal, P. O. Iversen, and M. Sioud, "Combination of endostatin and a protein kinase Calpha DNA enzyme improves the survival of rats with malignant glioma," Neoplasia (New York, N.Y.), vol. 4, no. 6, pp. 474479, 2002.

[102] E. N. Kontomanolis, A. Koutras, A. Syllaios et al., "Role of oncogenes and tumor-suppressor genes in carcinogenesis: a 
review," Anticancer research, vol. 40, no. 11, pp. 6009-6015, 2020.

[103] S. H. Hassanpour and M. Dehghani, "Review of cancer from perspective of molecular," Journal of Cancer Research and Practice, vol. 4, no. 4, pp. 127-129, 2017.

[104] T. Victor, R. Du Toit, A. M. Jordaan, A. J. Bester, and P. D. van Helden, "No evidence for point mutations in codons 12,13 , and 61 of the ras gene in a high-incidence area for esophageal and gastric cancers," Cancer research, vol. 50, no. 16, pp. 4911-4914, 1990.

[105] Y. S. Chang, K. T. Yeh, N. C. Hsu, S. H. Lin, T. J. Chang, and J. G. Chang, "Detection of N-, H-, and KRAS codons 12, 13, and 61 mutations with universal RAS primer multiplex PCR and N-, H-, and KRAS-specific primer extension," Clinical biochemistry, vol. 43, no. 3, pp. 296-301, 2010.

[106] G. A. Repasky, E. J. Chenette, and C. J. Der, "Renewing the conspiracy theory debate: does Raf function alone to mediate Ras oncogenesis?," Trends in cell biology, vol. 14, no. 11, pp. 639-647, 2004.

[107] S. H. Yu, T. H. Wang, and L. C. Au, "Specific repression of mutant K-RAS by 10-23 DNAzyme: sensitizing cancer cell to anti-cancer therapies," Biochemical and biophysical research communications, vol. 378, no. 2, pp. 230-234, 2009.

[108] D. Jang, Y. M. Baek, H. Park, Y. E. Hwang, and D. E. Kim, "Dual effects of a CpG-DNAzyme targeting mutant EGFR transcripts in lung cancer cells: TLR9 activation and EGFR downregulation,” BMB reports, vol. 51, no. 1, pp. 27-32, 2018.

[109] F. Ciardiello and G. Tortora, "A novel approach in the treatment of cancer: targeting the epidermal growth factor receptor," Clinical cancer research : an official journal of the American Association for Cancer Research, vol. 7, no. 10, pp. 2958-2970, 2001.

[110] I. Y. Tam, L. P. Chung, W. S. Suen et al., "Distinct epidermal growth factor receptor and KRAS mutation patterns in nonsmall cell lung cancer patients with different tobacco exposure and clinicopathologic features," Clinical cancer research : an official journal of the American Association for Cancer Research, vol. 12, no. 5, pp. 1647-1653, 2006.

[111] J. T. Schiller and D. R. Lowy, "Vaccines to prevent infections by oncoviruses," Annual review of microbiology, vol. 64, pp. 23-41, 2010.

[112] R. Sarid and S. J. Gao, "Viruses and human cancer: from detection to causality," Cancer letters, vol. 305, no. 2, pp. 218-227, 2011.

[113] L. Yang, Z. Lu, X. Ma, Y. Cao, and L. Q. Sun, “A therapeutic approach to nasopharyngeal carcinomas by DNAzymes targeting EBV LMP-1 gene," Molecules (Basel, Switzerland), vol. 15, no. 9, pp. 6127-6139, 2010.

[114] A. G. Eliopoulos and L. S. Young, "LMP1 structure and signal transduction," Seminars in cancer biology, vol. 11, no. 6, pp. 435-444, 2001.

[115] C. W. Dawson, L. Laverick, M. A. Morris, G. Tramoutanis, and L. S. Young, "Epstein-Barr virus-encoded LMP1 regulates epithelial cell motility and invasion via the ERKMAPK pathway," Journal of virology, vol. 82, no. 7, pp. 3654-3664, 2008.

[116] Z. X. Lu, M. Ye, G. R. Yan et al., "Effect of EBV LMP1 targeted DNAzymes on cell proliferation and apoptosis," Cancer gene therapy, vol. 12, no. 7, pp. 647-654, 2005.

[117] X. Ke, Y. C. Yang, and S. L. Hong, "EBV-LMP1-targeted DNAzyme restrains nasopharyngeal carcinoma growth in a mouse C666-1 xenograft model," Medical oncology (Northwood, London, England), vol. 28, Suppl 1, pp. S326-S332, 2011.

[118] H. Hausenzur, "Papillomavirus infections-a major cause of human cancers," Biochimica et biophysica acta, vol. 1288, no. 2, pp. F55-F78, 1996.

[119] E. M. Burd, "Human papillomavirus and cervical cancer," Clinical microbiology reviews, vol. 16, no. 1, pp. 1-17, 2003.

[120] P. Reyes-Gutiérrez and L. M. Alvarez-Salas, "Cleavage of HPV-16 E6/E7 mRNA mediated by modified 10-23 deoxyribozymes,” Oligonucleotides, vol. 19, no. 3, pp. 233-242, 2009.

[121] B. A. Werness, A. J. Levine, and P. M. Howley, "Association of human papillomavirus types 16 and 18 E6 proteins with p53," Science (New York, N.Y.), vol. 248, no. 4951, pp. 7679, 1990, https://doi.org/10.1126/science.2157286.

[122] C. M. Yashar, "23 - basic principles in gynecologic radiotherapy," Clinical Gynecologic Oncology, D. S. PJ, W. T. Creasman, R. S. Mannel, M. M. DS, and D. G. Mutch, Eds., 586605.e583, 2018.

[123] L. Tang, F. Wei, Y. Wu et al., "Role of metabolism in cancer cell radioresistance and radiosensitization methods," Journal of experimental \& clinical cancer research : CR, vol. 37, no. 1, p. 87, 2018.

[124] Y. Cao, L. Yang, W. Jiang et al., “Therapeutic evaluation of Epstein-Barr virus-encoded latent membrane protein-1 targeted DNAzyme for treating of nasopharyngeal carcinomas," Molecular therapy: the journal of the American Society of Gene Therapy, vol. 22, no. 2, pp. 371-377, 2014.

[125] W. Chen and G. H. Hu, "Biomarkers for enhancing the radiosensitivity of nasopharyngeal carcinoma," Cancer biology \& medicine, vol. 12, no. 1, pp. 23-32, 2015.

[126] Z. X. Lu, X. Q. Ma, L. F. Yang et al., "DNAzymes targeted to EBV-encoded latent membrane protein-1 induce apoptosis and enhance radiosensitivity in nasopharyngeal carcinoma," Cancer letters, vol. 265, no. 2, pp. 226-238, 2008.

[127] J. E. Ziello, I. S. Jovin, and Y. Huang, "Hypoxia-inducible factor (HIF)-1 regulatory pathway and its potential for therapeutic intervention in malignancy and ischemia," The Yale journal of biology and medicine, vol. 80, no. 2, pp. 51-60, 2007.

[128] E. B. Rankin and A. J. Giaccia, "The role of hypoxia-inducible factors in tumorigenesis," Cell death and differentiation, vol. 15, no. 4, pp. 678-685, 2008.

[129] B. J. Moeller and M. W. Dewhirst, "HIF-1 and tumour radiosensitivity," British journal of cancer, vol. 95, no. 1, pp. 1-5, 2006.

[130] G. Niu and X. Chen, "Vascular endothelial growth factor as an anti-angiogenic target for cancer therapy," Current drug targets, vol. 11, no. 8, pp. 1000-1017, 2010.

[131] Y. Ohnuma, M. Toda, M. Fujita et al., "Blockade of an angiotensin type I receptor enhances effects of radiation on tumor growth and tumor-associated angiogenesis by reducing vascular endothelial growth factor expression," Biomedicine \& pharmacotherapy = Biomedecine \& pharmacotherapie, vol. 63, no. 2, pp. 136-145, 2009.

[132] L. Yang, L. Liu, Z. Xu et al., "EBV-LMP1 targeted DNAzyme enhances radiosensitivity by inhibiting tumor angiogenesis via the JNKs/HIF-1 pathway in nasopharyngeal carcinoma," Oncotarget, vol. 6, no. 8, pp. 5804-5817, 2015.

[133] M. Kulis and M. Esteller, "DNA methylation and cancer," Advances in genetics, vol. 70, pp. 27-56, 2010. 
[134] M. Esteller, "Epigenetics in cancer," The New England journal of medicine, vol. 358, no. 11, pp. 1148-1159, 2008.

[135] X. Wang, L. Zhang, N. Ding et al., "Identification and characterization of DNAzymes targeting DNA methyltransferase I for suppressing bladder cancer proliferation," Biochemical and biophysical research communications, vol. 461, no. 2, pp. 329-333, 2015.

[136] J. Zhang, C. Yang, C. Wu, W. Cui, and L. Wang, "DNA methyltransferases in cancer: biology, paradox, aberrations, and targeted therapy," Cancers, vol. 12, no. 8, p. 2123, 2020.

[137] Y. Kanai, S. Ushijima, Y. Nakanishi, M. Sakamoto, and S. Hirohashi, "Mutation of the DNA methyltransferase (DNMT) 1 gene in human colorectal cancers," Cancer letters, vol. 192, no. 1, pp. 75-82, 2003.

[138] A. Li, N. Omura, S. M. Hong, and M. Goggins, "Pancreatic cancer DNMT1 expression and sensitivity to DNMT1 inhibitors," Cancer biology \& therapy, vol. 9, no. 4, pp. 321-329, 2010.

[139] T. Etoh, Y. Kanai, S. Ushijima et al., "Increased DNA methyltransferase 1 (DNMT1) protein expression correlates significantly with poorer tumor differentiation and frequent DNA hypermethylation of multiple CpG islands in gastric cancers," The American journal of pathology, vol. 164, no. 2, pp. 689699, 2004.

[140] J. Yoo, J. H. Kim, K. D. Robertson, and J. L. Medina-Franco, "Molecular modeling of inhibitors of human DNA methyltransferase with a crystal structure: discovery of a novel DNMT1 inhibitor," Advances in protein chemistry and structural biology, vol. 87, pp. 219-247, 2012.

[141] S. D. Patil, D. G. Rhodes, and D. J. Burgess, "DNA-based therapeutics and DNA delivery systems: a comprehensive review,” The AAPS journal, vol. 7, no. 1, pp. E61-E77, 2005.

[142] R. Bhindi, R. G. Fahmy, H. C. Lowe et al., "Brothers in arms: DNA enzymes, short interfering RNA, and the emerging wave of small-molecule nucleic acid-based gene-silencing strategies," The American journal of pathology, vol. 171, no. 4, pp. 1079-1088, 2007.

[143] M. Chakravarthy, M. T. Aung-Htut, B. T. le, and R. N. Veedu, "Novel chemically-modified DNAzyme targeting integrin alpha-4 RNA transcript as a potential molecule to reduce inflammation in multiple sclerosis," Science Reports, vol. 7, no. 1, p. 1613, 2017.

[144] A. A. Fokina, B. P. Chelobanov, M. Fujii, and D. A. Stetsenko, "Delivery of therapeutic RNA-cleaving oligodeoxyribonucleotides (deoxyribozymes): from cell culture studies to clinical trials," Expert opinion on drug delivery, vol. 14, no. 9, pp. 1077-1089, 2017.

[145] M. Petersen, K. Bondensgaard, J. Wengel, and J. P. Jacobsen, "Locked nucleic acid (LNA) recognition of RNA: NMR solution structures of LNA:RNA hybrids," Journal of the American Chemical Society, vol. 124, no. 21, pp. 5974-5982, 2002.

[146] A. Khan, M. Benboubetra, P. Z. Sayyed et al., "Sustained polymeric delivery of gene silencing antisense ODNs, siRNA, DNAzymes and ribozymes: in vitro and in vivo studies," Journal of drug targeting, vol. 12, no. 6, pp. 393-404, 2004.

[147] S. H. Pun, F. Tack, N. C. Bellocq et al., "Targeted delivery of RNA-cleaving DNA enzyme (DNAzyme) to tumor tissue by transferrin-modified, cyclodextrin-based particles," Cancer biology \& therapy, vol. 3, no. 7, pp. 641-650, 2004.

[148] J. Zhang, D. Wu, Z. Xing et al., "N-Isopropylacrylamidemodified polyethylenimine-mediated p53 gene delivery to prevent the proliferation of cancer cells," Colloids and surfaces. B, Biointerfaces, vol. 129, pp. 54-62, 2015.

[149] F. Tack, A. Bakker, S. Maes et al., "Modified poly(propylene imine) dendrimers as effective transfection agents for catalytic DNA enzymes (DNAzymes)," Journal of drug targeting, vol. 14, no. 2, pp. 69-86, 2006.

[150] F. Tack, M. Noppe, A. Van Dijck et al., "Delivery of a DNAzyme targeting c-myc to HT29 colon carcinoma cells using a gold nanoparticulate approach," Die Pharmazie, vol. 63, no. 3, pp. 221-225, 2008.

[151] C. W. Chan and L. M. Khachigian, "DNAzyme delivery approaches in biological settings," Current Medicinal Chemistry, vol. 20, no. 28, pp. 3448-3455, 2013.

[152] T. Tejada-Berges, C. O. Granai, M. Gordinier, and W. Gajewski, "Caelyx/Doxil for the treatment of metastatic ovarian and breast cancer," Expert review of anticancer therapy, vol. 2, no. 2, pp. 143-150, 2002.

[153] C. R. Dass, A. M. Friedhuber, L. M. Khachigian, D. E. Dunstan, and P. F. Choong, "Downregulation of c-jun results in apoptosis-mediated anti-osteosarcoma activity in an orthotopic model," Cancer biology \& therapy, vol. 7, no. 7, pp. 10331036, 2008.

[154] K. Roy, H. Q. Mao, S. K. Huang, and K. W. Leong, "Oral gene delivery with chitosan-DNA nanoparticles generates immunologic protection in a murine model of peanut allergy," Nature medicine, vol. 5, no. 4, pp. 387-391, 1999.

[155] C. R. Dass, A. M. Friedhuber, L. M. Khachigian, D. E. Dunstan, and P. F. Choong, "Biocompatible chitosan-DNAzyme nanoparticle exhibits enhanced biological activity," Journal of microencapsulation, vol. 25, no. 6, pp. 421-425, 2008.

[156] M. L. Tan, D. E. Dunstan, A. M. Friedhuber, P. F. Choong, and C. R. Dass, "A nanoparticulate system that enhances the efficacy of the tumoricide Dz13 when administered proximal to the lesion site," Journal of controlled release : official journal of the Controlled Release Society, vol. 144, no. 2, pp. 196-202, 2010.

[157] M. L. Tan, A. M. Friedhuber, and C. R. Dass, “Co-nanoencapsulated doxorubicin and Dz13 control osteosarcoma progression in a murine model," The Journal of pharmacy and pharmacology, vol. 65, no. 1, pp. 35-43, 2013. 